\title{
Noble Metal Nanoparticles-Based Colorimetric Biosensor for Visual Quantification: A Mini Review
}

\author{
Lu Yu* and Na Li
}

Department of Mechanical and Aerospace Engineering, University of Miami, Coral Gables, FL 33146, USA

* Correspondence: 1.yu5@umiami.edu

Abstract: Nobel metal can be used to form a category of nanoparticles, termed noble metal nanoparticles (NMNPs), which are inert (resistant to oxidation/corrosion) and have unique physical and optical properties. NMNPs, particularly gold and silver nanoparticles (AuNPs and AgNPs), are highly accurate and sensitive visual biosensors for the analytical detection of a wide range of inorganic and organic compounds. The interaction between noble metal nanoparticles (NMNPs) and inorganic/organic molecules produces colorimetric shifts that enable the accurate and sensitive detection of toxins, heavy metal ions, nucleic acids, lipids, proteins, antibodies, and other molecules. Hydrogen bonding, electrostatic interactions, and steric effects of inorganic/organic molecules with NMNPs surface can react or displacing capping agents, inducing crosslinking and non-crosslinking, broadening, or shifting local surface plasmon resonance absorption. NMNPs-based biosensors have been widely applied to a series of simple, rapid, and low-cost diagnostic products using colorimetric readout or simple visual assessment. In this mini review, we introduce the concepts and properties of NMNPs with chemical reduction synthesis, tunable optical property, and surface modification technique that benefit the development of NMNPs-based colorimetric biosensors, especially for the visual quantification. The "aggregation strategy" based detection principle of NMNPs colorimetric biosensors with the mechanism of crosslinking and non-crosslinking have been discussed, particularly, the critical coagulation concentration-based salt titration methodology have been exhibited by derived equations to explain non-crosslinking strategy be applied to NMNPs based visual quantification. Among the broad categories of NMNPs based biosensor detection analyses, we typically focused on four types of molecules (melamine, single/double strand DNA, mercury ions, and proteins) with discussion from the standpoint of the interaction between NMNPs surface with molecules, and DNA engineered NMNPs-based biosensor applications. Taken together, NMNPs-based colorimetric biosensors have the potential to serve as a simple yet reliable technique to enable visual quantification.

Keywords: noble metal nanoparticles; colorimetric; biosensor; critical coagulation concentration; salt titration; melamine; single/double stranded DNA; $\mathrm{Hg}^{2+}$; proteins

\section{Introduction}

Noble metals include ruthenium, rhodium, palladium, silver, osmium, iridium, platinum, and gold. Key features of the metals are resistance to oxidation/corrosion and scarcity in the earth's crust. The bulk of the noble metal nanoparticles (NMNPs) center around gold and silver nanoparticles (AuNPs and AgNPs) [1]. NMNPs have attracted interest from researchers due to their tunable and unique physical and biochemical properties [2,3]. By formulating noble metals into nanoscale materials, their shape, surface charge, composition, and chemical functionality impart unique capabilities in a variety of biological, engineering, and biomedical applications [4,5]. Their ease of synthesis, chemical durability, functional flexibility, biocompatibility, and low toxicity afford NMNPs a wide range of applications. The purpose of this mini-review is to analyze and interpret the development of 
NMNPs-based colorimetric biosensor for visual detection in recent years. The main idea throughout the mini-review is primarily focused on the NMNPs-based "aggregation strategy", with the discussion of two main types (crosslink and non-crosslink). We primarily focus on four types of representative analyses (melamine, single/double strand DNA, mercury ions, and proteins) as typical examples of presenting the development of NMNPs-based colorimetric biosensor detection. For each type of analyses, the mini-review is focus on the interaction between NMNPs surface and molecules by electrostatic, hydrogen bonding, surface potential, and etc., and DNA engineered NMNPs as colorimetric biosensors for visual quantification. We also survey each type analyses with one or two reported classic sensing examples, followed with recent reported interesting results and discussed with benefits, challenges, and future directions.

\subsection{NMNPs Synthesis}

Recently, numerous strategies have been developed to enhance the functionality of NMNPs, particularly by precisely controlling size, shape, and monodisperse of the nanoparticles (Figure 1). The most common synthetic preparations of NMNPs follow the methods that were set forth by Turkevich and Frens [6-11]. The Turkevich method is based on a single-phase metal salt redox reaction with sodium citrate to produce spherical NMNPs. This redox reaction is carried out in a boiling aqueous citrate solution. In the reaction, citrate serves as a reducing agent, capping agent, and buffering agent. In a typical AuNPs preparation, the mole ratio of $\mathrm{HAuCl}_{4}$ and sodium citrate are crucial in proper formulation. The amount of sodium citrate determines the $\mathrm{pH}$ in this reaction. As the hydrolysis of $\mathrm{HAuCl}_{4}$ take place, different precursors would form at different $\mathrm{pK}_{\mathrm{a}}$ value with components, such as (a) $\mathrm{AuCl}_{3}(\mathrm{OH})^{-}$, (b) $\mathrm{AuCl}_{2}(\mathrm{OH})_{2}{ }^{-}$, (c) $\mathrm{AuCl}(\mathrm{OH})_{3}{ }^{-}$, and (d) $\mathrm{Au}(\mathrm{OH})_{3}$. The sodium citrate is oxidized to form sodium acetone dicarboxylate and it induces the reduction of several auric precursors to $\mathrm{AuCl}$ during the $\mathrm{pH}$ dependent reaction process. Using this method, monodispersed spherical AuNPs can be synthesized, and, based on $\mathrm{pH}$ of the reaction, nanoparticle size can be tuned, resulting in particles with diameters that ranged from $10 \mathrm{~nm}$ to $100 \mathrm{~nm}$ [12]. The Turkevich method has also been utilized with Ag ions by using sodium citrate and silver nitrate to synthesize monodisperse quasi-spherical nanoparticles [13,14]. Again, pH is still the major consideration to control nanoparticle size. Sodium citrate acts as a reducing agent and stabilizer to induce a reduction of $\left[(\mathrm{Ag})_{2}{ }^{+}\right.$-Citrate $]$ions, thereby playing a key role in reducing Ag ions to AgNPs with a kinetic growth behavior. Tannic acid has also been used as an effective stabilizer and reducer, and polyvinylpyrrolidone (PVP) have been used as co-surface stabilizer and growth modifier to further improve the spherical AgNPs synthesize with a monodispersed size of $5 \mathrm{~nm}$ [15]. Another common NMNP synthesis protocol implements the earlier work of Brust and Schriffin [16-19]. The Brust method involves a two-phase metal salt reduction by sodium borohydride $\left(\mathrm{NaBH}_{4}\right)$ in the presence of an alkanethiol stabilizer. In a typical AuNPs preparation, tetra-n-octylammonium bromide (TOAB) is utilized as a phase transfer catalyst of $\mathrm{AuCl}_{4}{ }^{-}$ from the aqueous to organic phase. The phase transfer of $\mathrm{AuCl}_{4}{ }^{-}$forms AuNPs with a tunable size from 1 to $5 \mathrm{~nm}$. This preparation of AuNPs enables their surface to be coated with a monolayer alkanethiol that can be modified with various functional groups. This alkanethiol monolayer also provides AuNPs much greater stability, eases drying, purification, and enhances the stability of the nanoparticle suspension. The procedure to synthesize AgNPs utilizes TOAB dissolved in toluene as a two-phase transfer system. For this method, aqueous $\mathrm{AgNO}_{3}$ is dropped solution, followed by $\mathrm{NaBH}_{4}$ as reducing agent and alkanethiol as a chemical stabilizer [20]. 


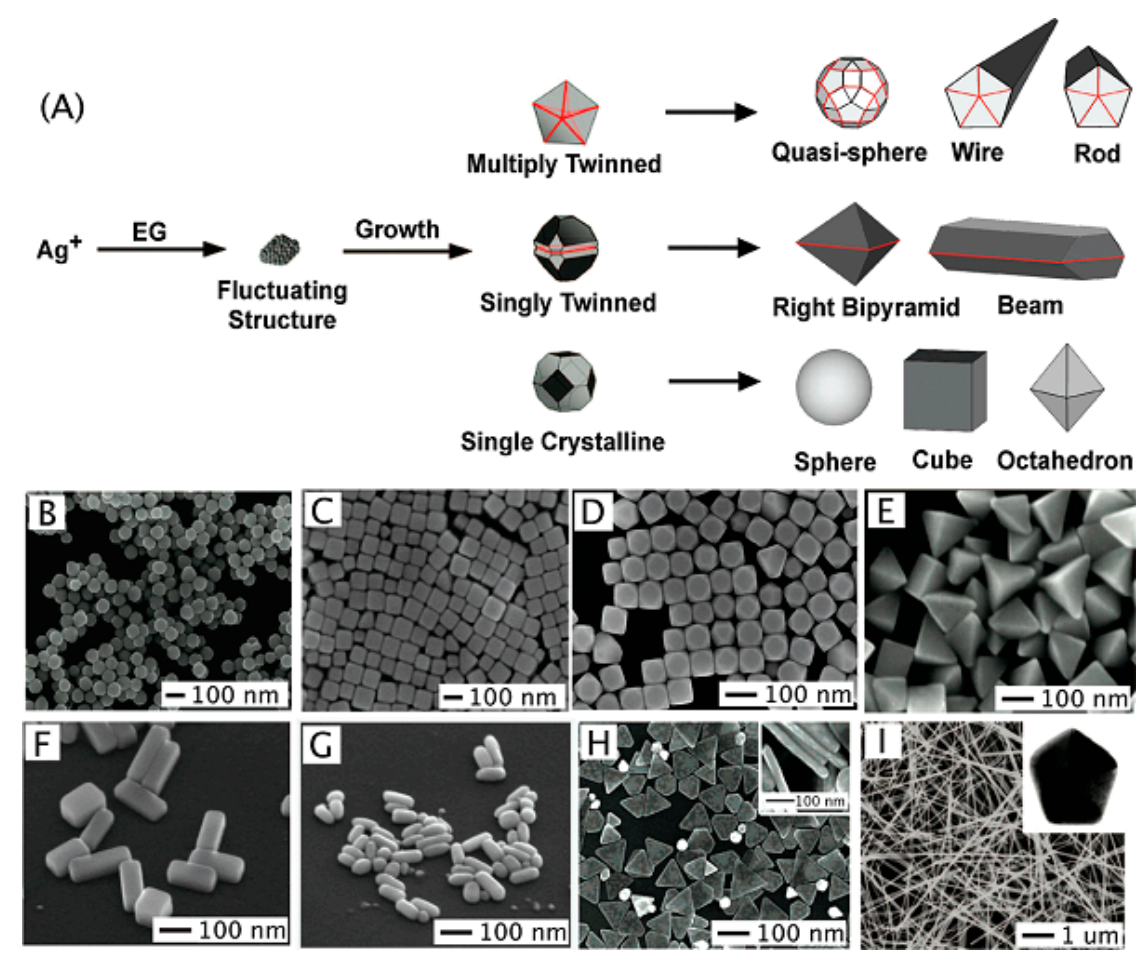

Figure 1. Synthesizing Ag nanostructures: (A) ethylene glycol (EG) leads to the formation of nuclei. As the nuclei grow, fluctuations cease and their structure becomes static and contains multiply twinned boundary defects, single twinned boundary defects, or are single crystalline with no boundary defects. The seeds are then grown into different nanostructures like (B) spheres, (C) cubes, (D) truncated cubes, (E) right bipyramids, (F) bars, (G) spheroids, (H) triangular plates, and (I) wires. Reprinted with permission from Chemical Reviews, 2011, 111, 6, 3669-3712. Copyright (2011) American Chemical Society.

In addition to two optimal methodologies, other chemical reduction based NMNPs synthesis methods (sodium borohydride, seeding/growth, green synthesis, ionic liquids-based, and etc.) provided NMNPs as a versatile platform for NMNPs-based colorimetric biosensor development [20,21]. When comparing with two classic NMNPs synthesis strategies, seeding/growth is another most simple, efficient, and versatile method for preparing high quality NMNPs [22,23]. During the first stage of seeding/growth synthesis, metal precursor has been used to form nanoseeds by the reducing agent. Utilizing the cationic surfactants by adsorbing onto specific seed facets, the nanoseeds could further grow into NMNPs during the second stage of synthesis. A small concentration of additional ions has been used to control the NMNPs aspect ratio. By separating nucleation (first stage) and growth (second stage), NMNPs could be exactly prepared with uniform size and size distribution by this convenience method in a large reaction scale. Furthermore, the water-immiscible ionic liquid is another emerging method for preparing NMNPs in recent years. The ionic liquids (ILs) can be employed as a medium to transfer NMNPs from the aqueous phase to the organic phase. Unlike the Brust method, NMNPs synthesized by the ILs method could be preserved during the phase transfer without capping of thiols and amines. By tuning the size and shape, NMNPs could be obtained by large reaction scale, as the ILs play as reducing and capping agents [24-26]. In sum, all of the methods are extensively used in NMNPs synthesis, which offers NMNPs a fundamental breakthrough that has advanced research in the NMNPs-based biosensor technique.

\subsection{Unique Optical Properties}

Colloidal solutions of NMNPs display bright intense reflected colors due to their unique interaction with visual light $[27,28]$. This optical enhancement arises from the NMNPs free electrons that endure as a collective coherent oscillation that produces a surface plasma state (Figure 2). NMNPs surface 
plasmas resonate at a particular frequency and this surface plasmonic resonance phenomenon is termed as the localized surface plasmon resonance (SPR) [29]. The SPR oscillation decays by radiating its energy converting this energy into scattered light. The particle shape, geometry, degree of interaction with adjacent particles, dielectric function of NMNPs, and the presence of nearby dielectric objects determine the light scattering. The quasi-static approximation framework has been used to analyze the influence of the factors (geometrical size and dielectric environment) with the SPR effect. The particle diameter $(d)$ and an electromagnetic wavelength $(\lambda)$ should be under the condition of $d$ $\lambda$ for small particles. When $\mathrm{d}$ approaches the nanoscale with a homogenous state in medium with a dielectric constant, the oscillating dipole moment $(\mathrm{p})$ could be described, as following:

$$
\mathrm{p}(\mathrm{t})=\varepsilon_{0} \varepsilon_{\mathrm{m}} \alpha \psi \mathrm{E}_{0} \mathrm{e}^{-\mathrm{i} \omega \mathrm{t}}
$$

with $\varepsilon_{\mathrm{m}}$ and $\varepsilon_{0}$ as dielectric constant, $\alpha$ as the complex polarizability, $\mathrm{E}_{0}$ as applied field, and $\omega$ as the angular frequency $(\omega=2 \pi \cdot c / \lambda)$.
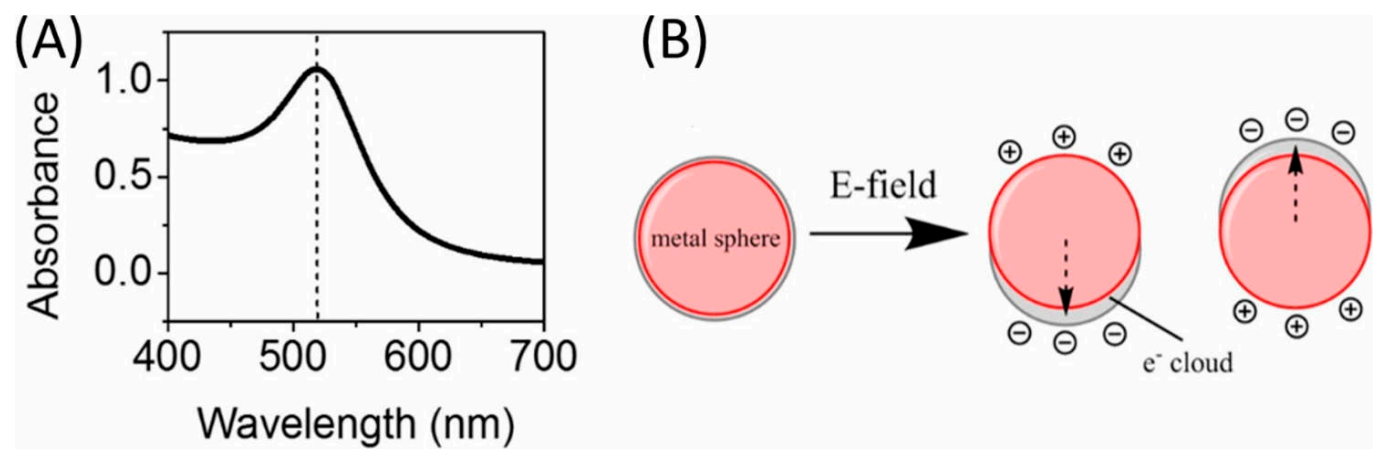

Figure 2. The schematic illustration of (A) UV spectrum of $13 \mathrm{~nm}$ AuNPs colloid system and (B) the oscillation of conduction electrons across the AuNPs in the electromagnetic field of the incident light.

All NMNPs have a characteristic extinction coefficient in visible light and AuNPs/AgNPs have particularly high molar extinction coefficients $\left(1 \times 10^{8}\right.$ to $\left.1 \times 10^{10} \mathrm{M}^{-1} \mathrm{~cm}^{-1}\right)$. Therefore, AuNPs and AgNPs have superior optical properties to other metal nanoparticles as probes for visual detection. For instance, monodispersed spherical AuNPs have a red wine color. This color is from AuNPs absorption of light in the green-blue range (about $450 \mathrm{~nm}$ ) and the reflection of red wavelengths (approximately $700 \mathrm{~nm}$ ). As the AuNPs size, shape, interparticle distance, and dielectric environment vary, the boarding surface plasma absorption shifts localized SPR frequency by moving from visible to invisible (near infrared) wavelengths. This color shift is a key phenomenon that make it potential to develop colorimetric visual biosensors. AgNPs also share many interesting phenomena with AuNPs. They can absorb and scatter light via the SPR effect with an especially intense surface plasmon absorption band that peaks at $400 \mathrm{~nm}$. AgNPs have a stronger extinction coefficient $(1000 \times)$, the same size AuNPs, and the optical properties of AgNPs can also be tuned by controlling the size, shape, interparticle distance, and altering surface ligands [30]. Hence, AuNPs and AgNPs with physical and chemical properties, like higher extinction coefficient and strong surface plasmon resonance (SPR) absorption make them particularly suitable as visual detection probes.

\subsection{Surface Modification}

The NMNPs surface modification is important for controlling NMNPs size by increasing colloidal stability and providing new functionality to the NMNPs (Figure 3). Electrostatic, steric, or a combination of both force maintain colloid system stability [31,32]. The electrostatic repulsion, steric exclusion, and hydration layer on the NMNPs surface are three main repulsive forces that prevent NMNPs aggregation in aqueous solution. As a typical example of AuNPs that were prepared via the Turkevich method, electrostatic repulsion is the main force to maintain AuNPs stability. Ligands need to be attached to the 
AuNPs surface by stronger covalent bonds to improve repulsion force. As a typical example of Brust method prepared AuNPs, an alkanethiol stabilizer is produced with gold-thiol chemistry to provide AuNPs surface with a self-assembling monolayer (SAM) enhancing the hydrophobic effect to prevent aggregation with a much smaller monodispersed size than the Turkevich method.

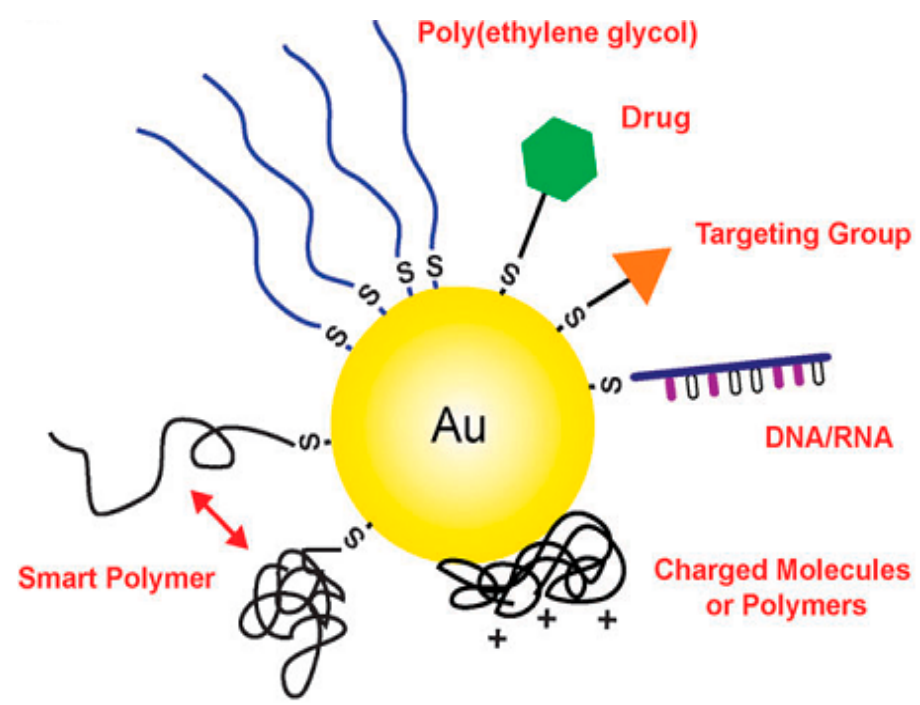

Figure 3. Gold nanostructures can be conjugated with a wide variety of functional moieties, both through the gold-thiolate bond and by passive adsorption. Reprinted with permission from Chemical Society Reviews, 2011, 40, 44-56. Copyright (2011) American Chemical Society.

Additionally, AuNPs can gain new functionality while using a ligand exchange reaction. Citrate groups can be exchanged with bifunctional ligand molecules (containing both carboxylic acid and thiol groups) through electrostatic interactions to attach new ligands onto the Turkevich prepared AuNPs. With the assistance of destabilizing salts, AuNPs can be precipitated and ligands can be exchanged onto the surface of AuNPs [33,34]. In the literature, interesting phenomena based on ligand exchange include sensing, imaging, and self-assembly of nanoparticles. Thiol groups showed great affinity with the NMNPs surface, especially in covalent bonds with gold. The degree of ligand exchange is related to the reaction time and ligand feed ratio with NMNPs. In addition to covalent thiol/metal interaction, non-covalent/physical adsorption is another way of providing conjugate ligands, such as bovine serum amino oxidase by aminic groups onto NMNPs surface [35]. Other conjugation methods, such as click chemistry based $\mathrm{Cu}(\mathrm{I})$-catalysed azide-alkyne cycloaddition and carbohydrates using strain-promoted azide-alkyne cycloaddition (SPAAC), also provide NMNP surfaces with a wider functional activity [36,37].

\section{Principle of NMNPs Visual Detection Strategies}

NMNPs are ideal colorimetric probes for visual biosensor research. Utilizing their unique visual properties that are derived from their SPR and extinction characteristics, many biological and medical applications have been developed while using NMNPs, especially AuNPs and AgNPs as colorimetric probes [38-42]. AuNPs and AgNPs based "aggregation strategy" biosensors could be predominantly divided into two major types that are based on the mode of analyses induced nanoparticles aggregation mechanisms: crosslinking and non-crosslinking. Based on each type of aggregation mechanism, NMNPs produce a visible color change when molecules of interest reach a critical concentration threshold. The detecting molecules that induce NMNPs aggregation have a specific chemical group that can react or physically interact with the NMNPs surface ligand, or alter the NMNPs dielectric environment. The reactions and/or interactions produce a linear relationship between NMNPs colorimetric readout that corresponds to the detecting molecules concentration. Thereby, NMNPs provide a great platform for visual biosensor and many biosensors have been 
developed by using AuNPs or AgNPs as colorimetric probes for sensitive and selective detection of molecules. The strategy that is based on the analyses that can trigger the altering of NMNPs size, shape, and degree of interaction by the "non-aggregation" strategy (etching or the growth) is another branch of NMNPs colorimetric biosensor research field [43]. In this mini-review, we are particular focusing on the NMNPs-based "aggregation strategy" and its colorimetric biosensor applications.

\subsection{Two Major Types of NMNPs-Based Colorimetric Biosensors}

The principle of NMNP crosslinking-based colorimetric biosensors is predicated on the specific interaction between detecting molecules and surface modified ligands. The ligands have been designed with a functional group (amine- or thiol-) to covalently bond to the NMNPs surface and a second group designed with a specific chemical structure that could capture the detecting molecules by intermolecular interaction (e.g., electrostatic interactions, hydrogen bonding, hydrophobic interactions, van der Waals forces) [44]. Different types of functionalized ligands, such as short chain organic molecules, have been synthesized and modified onto NMNPs surfaces [45-47]. Thiol-gold chemistry is the most popular method for AuNPs modification [48-50]. The ligands with thiolate group could covalently attach to the AuNPs surface by a gold-thiol reaction. Different ligands, such as peptides, antibodies, single stranded oligonucleotides, and aptamers, have been modified onto the surface of AuNPs by gold-thiol reactions to improve sensitivity and selectivity [51-55]. Various molecules, such as toxic heavy ions, pesticide residues, drugs, proteins, and nucleic acids, have been accurately detected at extremely low concentrations while using the techniques [56-58]. When the concentration of the molecule(s) of interest reach a critical point, AuNPs crosslinking aggregation begins, and this, in turn, produces a spectrum of color change in the AuNPs corresponding to the concentration of the molecule(s) of interest. Herein, the amount of molecule(s) of interest could be determined by the AuNPs colorimetric readout and it is possible for the visual quantification by naked eyes without the assistance of a spectrophotometer.

For the NMNPs-based non-crosslinking, there is no requirement to label the functionalized ligand on NMNPs surface. For instance, the molecule(s) of interest can induce AuNPs into non-crosslinking aggregation by changing the surface potential, which, in turn, alters electrostatic double layer thickness and Debye length, ultimately determining the stability of the colloidal solution. Our group previously reported an unmodified AuNPs-based colorimetric biosensor for melamine detection [59]. The principle of this detection strategy utilizes the intrinsic interaction between melamine and the AuNPs surface by adjusting the surface potential to achieve detection. Similar strategies have been reported in other label-free AuNPs-based colorimetric biosensors that have been developed for the detection of various molecules [60-63]. The molecule(s) of interest have a common chemical structure with primary amine group or nitrogen atom on exocyclic ring, which can interact with the noble metal surface [64-66]. Single stranded DNA has been reported to attach to the surface of noble metals. Its base group, especially adenine, produces a very strong interaction with gold surface [67-69]. It is reported that oligonucleotides of different conformations could adsorb to AuNPs with a different binding strengths and produce AuNPs with differing degrees of aggregation [70,71]. Several label free colorimetric biosensors have been designed for specific detection of nucleic acid with an extreme accuracy even at low-concentrations based on this intrinsic interaction [72-74]. Herein, the unmodified AuNPs non-crosslinking aggregation strategy avoids the complications of AuNP surface modification. Additionally, this strategy has been used to develop assays that are comparable to the crosslinking biosensor strategy.

\subsection{Critical Coagulation Concentration-Based Salt Titration Strategies}

The critical coagulation concentration (CCC) strategy (Figure 4) as a visual biosensor was developed by Li et al. while using the NMNPs non-crosslinking strategy in 2014. Different from other NMNP-based strategies, the CCC depends on adjusting ion concentration or strength to determine the concentration of the molecule(s) of interest. Below, we have derived equations to explain this strategy 
principle. The Derjaguin and Ladau, Verwey and Overbeek (DLVO) theory is the classical explanation of the stability of a colloidal system. In the theory, two type forces: (a) the Van der Waals attraction and (b) the electrostatic double layer repulsion theoretically explains the stability of a colloidal solution. It was supposed that the interaction between two particles should be: (a) planar particle, (b) symmetric electrolyte, (c) high surface potential, and (d) two particles far enough apart [75]. The total interaction energy in DLVO theory is the summation of the above two forces, which is defined by:

$$
\mathrm{V}_{\mathrm{T}}=\mathrm{V}_{\mathrm{A}}+\mathrm{V}_{\mathrm{R}}=-\frac{\mathrm{Aa}}{12 \mathrm{~h}}+2 \pi \varepsilon_{\mathrm{r}} \varepsilon_{0} \alpha \psi_{0}^{2} \ln [1+\exp (-\kappa \mathrm{h})]
$$

where $V_{T}$ is the total interaction energy, $V_{A}$ is Van der Waals attraction energy, $V_{R}$ is electrostatic double layer repulsion energy, $\mathrm{A}$ is the Hamaker constant, $\mathrm{h}$ is the smallest distance between surfaces of two particles, a is particle radius, $\varepsilon_{\mathrm{r}}$ is the dielectric constant of water, $\varepsilon_{0}$ is electric permittivity of free space, $\psi_{0}$ is surface potential, and $\kappa$ is the inverse Debye length, which is defined by

$$
\kappa=\left[\frac{1000 \mathrm{e}^{2} \mathrm{~N}_{\mathrm{A}}(2 \mathrm{I})}{\varepsilon_{\mathrm{r}} \varepsilon_{0} \mathrm{kT}}\right]^{\frac{1}{2}}
$$

e is electric charge of electron, $\mathrm{N}_{\mathrm{A}}$ is Avogadro number, $\mathrm{I}$ is ionic strength, $\mathrm{k}$ is Boltzmann constant, and $\mathrm{T}$ is temperature.
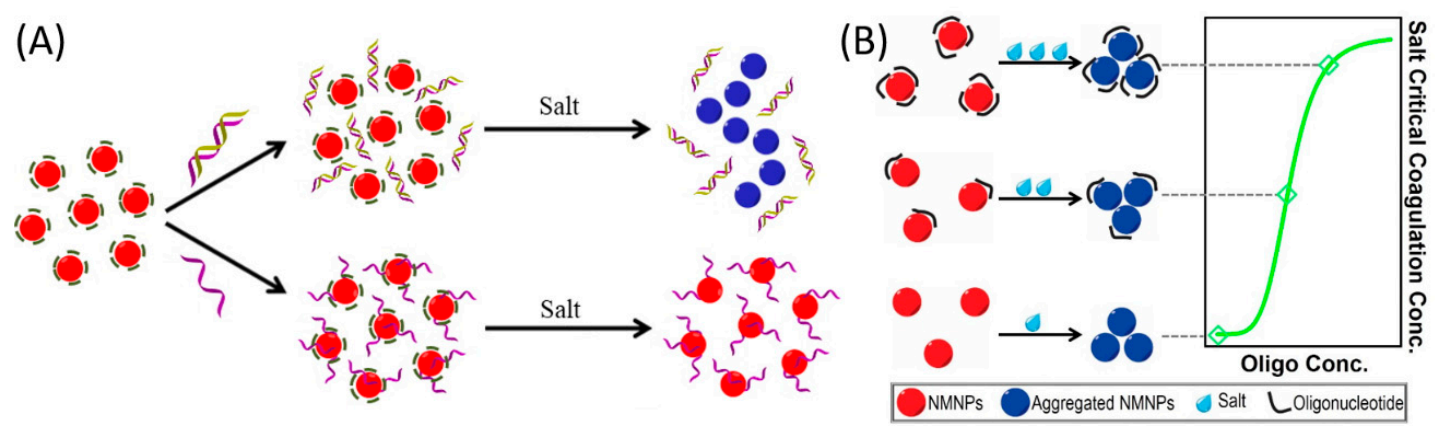

Figure 4. Schematic illustration of critical coagulation concentration based salt titration for visual quantification (A) AuNPs based colorimetric method for single strand and double DNA detection and (B) salt-titration based colorimetric method for determining the adsorption strength between NMNPs and oligonucleotides. Reprinted with permission from Journal of Laboratory Automation, 2014, 19, 82 and the 9th IEEE International Conference on Nano/Molecular Medicine and Engineering 2015, 15-18. Copyright (2014) SAGE Journals (2015) IEEE and Copyright Clearance Center.

The CCC is defined as the minimum concentration of counter ions to induce colloid system rapid coagulation $[76,77]$. The condition of the CCC is based on the total interaction energy

$$
\mathrm{V}_{\mathrm{T}}=0, \frac{\mathrm{dV} \mathrm{T}}{\mathrm{dh}}=0
$$

as we solve the Equation (4), we get

$$
\begin{aligned}
& \mathrm{V}_{\mathrm{T}}=-\frac{\mathrm{Aa}}{12 \mathrm{~h}^{2}}+\frac{2 \pi \varepsilon_{\mathrm{r}} \varepsilon_{0} \alpha \psi_{0}^{2}}{\mathrm{~h}} \ln [1+\exp (-\kappa \mathrm{h})]=0 \\
& \frac{\mathrm{dV}_{\mathrm{T}}}{\mathrm{dh}}=\frac{\mathrm{Aa}}{12 \mathrm{~h}^{2}}-\kappa 2 \pi \varepsilon_{\mathrm{r}} \varepsilon_{0} \alpha \psi_{0}^{2} \ln [1+\exp (-\kappa \mathrm{h})]=0
\end{aligned}
$$

by solving $h$ and $k$, we could get

$$
\mathrm{kh}=2
$$


by substituting k equation into Equation (5), we could get

$$
\mathrm{V}_{\mathrm{T}}=-\frac{\mathrm{Aa}}{24}\left[\frac{1000 \mathrm{e}^{2} \mathrm{~N}_{\mathrm{A}}(2 \mathrm{I})}{\varepsilon_{\mathrm{r}} \varepsilon_{0} \mathrm{kT}}\right]^{\frac{1}{2}}+2 \pi \varepsilon_{\mathrm{r}} \varepsilon_{0} \alpha \psi_{0}^{2} \ln [1+\exp (-2)]=0
$$

by solving the Equation (8), the CCC could be obtained,

$$
\mathrm{CCC}=\frac{0.039 \pi^{2} \varepsilon_{\mathrm{r}}^{3} \varepsilon_{0}^{3} \psi_{0}^{4} \mathrm{kT}}{\mathrm{A}^{2} \mathrm{e}^{2} \mathrm{~N}_{\mathrm{A}}}
$$

From the derived Equation (9), we find that the CCC is proportional to the fourth power of the surface potential. According to the Schulze-Hardy rule, CCC is proportional to the inverse sixth power of the counter ion valence [77-79]. This power relationship between CCC and surface potential indicates that CCC could be used as a very sensitive amplify read-out signal that increases detection accuracy to present the degree of surface potential change. As we know, the surface potential strength directly determines the colloidal solution stability. We assume that we could control the salt concentration by adjusting the electrostatic repulsive barrier to influence the colloid stability. As we see from the Equation (9), many other physical factors could also affect the colloidal stability. However, when compared to other factors, the ion concentration and strength is a simple and convenient method to analyze colloidal stability. Hence, we want to utilize the CCC-based salt titration strategy to develop a reliable way to visually quantify melamine concentration. CCC salt titration could be an elegant and sensitive detection method when compared to surface potential-based visual detection. Our group reported a salt titration method that is based upon the addition of an appropriate amount of salts to induce a small change of surface potential to detect melamine $[65,80]$. The analyses (melamine and nucleic acid) concentration corresponds to the CCC and they could be quantified by this strategy with high accuracy, even at extremely low concentrations.

\section{NMNPs Visual Detection Applications}

Utilizing NMNPs unique optical properties, NMNPs-based colorimetric biosensors have been widely reported to detect small organic molecules, toxic metal ions, oligonucleotides, and proteins in aqueous and physiological media [81-83]. Probes have been physically or chemically attached to the NMNPs surface to improve the sensitivity and specificity of detection performance. Currently, studies on the "aggregation strategy" of controlled nanostructures with other NMNPs geometries, such as rods and triangles, are in progress. In this mini-review, we are particularly focusing on spherical NMNPs-based (AuNPs and AgNPs with a small part of platinum nanoparticles (PtNPs)) biosensor applications by the "aggregation strategy". Melamine, single and double stranded DNA, $\mathrm{Hg}^{2+}$, and proteins have been selected as four types of analyses to exhibit NMNPs-based colorimetric biosensor performance by selectively and sensitively detecting molecules at an extremely low concentration (limited of detection (LOD)). Detailed discussion of other analyses (metal ions, anions, and small organic molecules) detected by NMNPs based biosensor has been suggested in other relative comprehensive reviews [81-83].

\subsection{Melamine Detection}

Melamine $\left(\mathrm{C}_{3} \mathrm{H}_{6} \mathrm{~N}_{6}\right)$ is a nitrogen rich chemical with a 1,3,5-triazine skeleton. It is widely used in industry to produce millions of tons of plastic resins per year. Melamine has been illegally added to food products in order to increase the apparent protein content (nitrogen content) because of the cheap price and high nitrogen content $(66 \%)$. Melamine has been reported to cause kidney failure by the formation of insoluble crystallized complexes. As a hot topic of food safety discussion, melamine has caused the deaths of thousands of pets, and thousands of Chinese babies to develop kidney stones. Undoubtedly, there is great need to develop reliable and highly sensitive sensors that can be used to detect melamine 
residues for food safety $[84,85]$. Conventional analytical instrument (e.g., chromatography spectrometry, mass spectrometry, capillary electrophoresis, infrared spectrometry, Raman spectrometry, and ELISA methods) have been reported as approaches for melamine detection [86]. The analytical techniques are sensitive, specific, and reliable; however, they are time consuming and require expensive instruments and complicated experimental protocols. An ideal analytical technique for melamine detection should be rapid, reliable, cost-effective, and it should not require expensive instrumentations or advanced training to perform the test. AuNPs and AgNPs as colorimetric probes for visual detection meet the criteria. The two main strategies for AuNPs/AgNPs-based colorimetric probes are surface ligand functionalized nanoparticles and unmodified nanoparticles. Based on the two strategies, AuNPs/AgNPs-based melamine detection methods have been widely reported for their specificity and sensitivity [87-90]. AuNPs/AgNPs-based colorimetric approaches with a high sensitivity and selectivity detection performance have been recently reported in the literatures (Table 1).

Table 1. Recent reported AuNPs/AgNPs-based colorimetric biosensors for melamine detection.

\begin{tabular}{|c|c|c|c|c|c|}
\hline Nanomaterials & $\begin{array}{l}\text { Detection } \\
\text { Probe }\end{array}$ & $\begin{array}{l}\text { Instruments } \\
\text { Employed }\end{array}$ & Interaction & $\begin{array}{l}\text { Detection } \\
\text { Limit }\end{array}$ & Ref \\
\hline AuNPs & Cyanuric acid & $\begin{array}{l}\text { Naked eyes } \\
\text { UV-vis }\end{array}$ & Hydrogen bonding & $0.3 \mu \mathrm{M}$ & [59] \\
\hline AuNPs & Salt & $\begin{array}{c}\text { Naked eyes } \\
\text { UV-vis }\end{array}$ & Surface Potential & $3.9 \mu \mathrm{M}$ & [65] \\
\hline AuNPs & Dithiothreitol & $\begin{array}{c}\text { Naked eyes } \\
\text { UV-vis }\end{array}$ & Hydrogen bonding & $24 \mathrm{nM}$ & [91] \\
\hline AuNPs & $\mathrm{H}_{2} \mathrm{O}_{2}$ & $\begin{array}{c}\text { Naked eyes } \\
\text { UV-vis }\end{array}$ & Hydrogen bonding & $0.4 \mu \mathrm{M}$ & [92] \\
\hline AuNPs & Melamine & Optical fiber & Surface Potential & $33 \mathrm{nM}$ & [93] \\
\hline AuNPs & Aptamer & $\begin{array}{l}\text { Naked eyes } \\
\text { UV-vis }\end{array}$ & Electrostatic & $0.4 \mathrm{nM}$ & [94] \\
\hline AuNPs & Size & UV-vis & $\begin{array}{c}\text { Surface Potential } \\
\text { Hydrogen }\end{array}$ & $1.1 \mathrm{nM}$ & [95] \\
\hline AuNPs & Aptamer/Salt & UV-vis & $\begin{array}{l}\text { bonding/Surface } \\
\text { Potential }\end{array}$ & $22 \mathrm{nM}$ & [96] \\
\hline AgNPs & Dopamine & $\begin{array}{l}\text { Naked eyes } \\
\text { UV-vis }\end{array}$ & Hydrogen bonding & $9.5 \mu \mathrm{M}$ & [97] \\
\hline AgNPs & Cyclodextrin & $\begin{array}{c}\text { Naked eyes } \\
\text { UV-vis }\end{array}$ & Hydrogen bonding & $5 \mu \mathrm{M}$ & [98] \\
\hline AgNPs & Ascorbic acid & $\begin{array}{c}\text { Naked eyes } \\
\text { UV-vis }\end{array}$ & Hydrogen bonding & $0.8 \mu \mathrm{M}$ & [99] \\
\hline AgNPs & Gallic acid & UV-vis & Hydrogen bonding & $3.6 \mathrm{nM}$ & [100] \\
\hline AgNPs & Succinic & UV-vis & Hydrogen bonding & $10 \mathrm{nM}$ & [101] \\
\hline AgNPs & Tannic acid & UV-vis & Hydrogen bonding & $10 \mathrm{nM}$ & [102] \\
\hline AgNPs & Unmodified & UV-vis & Surface Potential & $0.3 \mu \mathrm{M}$ & [103] \\
\hline
\end{tabular}

Utilizing the ligand functionalized approach, cyanuric acid derivatives can be conjugated onto the AuNPs surface [104]. As the cyanuric acid derivative could form a stable complex with melamine via hydrogen bonding, melamine could induce cyanuric acid derivative functionalized AuNPs to perform a self-assembly behavior. The self-assembly aggregation is a colorimetric phenomenon and it has to be utilized as a specific and sensitive method to detect melamine at an extremely low concentration. Similar ligands, such as 3-mercapto-1-propanesulfonate, 18-crown-6 ether, 4-amino-3-hydrazino-5-mercapto-1,2,4-triazol, and other molecules that form hydrogen bonds with melamine, have been attached to AuNPs and AgNPs for detection purpose [90,105]. Due to the complexity of the surface functionalization technique, unmodified AuNPs offer another attractive pathway for melamine detection. Li et al. reported an unmodified AuNPs-based colorimetric readout for the visual quantification of melamine [59]. The amine group and nitrogen atom on melamine exocyclic skeleton have an intrinsic interaction with the unmodified AuNPs surface. The surface 
attached melamine disturbs the stability of AuNPs colloid system by lowing the surface potential. Additionally, melamine reacts with cyanuric acid and forms a stable complex that produces turbid metric signal. With the dual signal readouts of colorimetric and turbid metrics, melamine could be quantitatively detected with great sensitivity by this strategy (Figure 5). Similar modified AuNPs platforms, such as chitosan, citrate capped, DNA, and bared surface surfactant strategies, have been reported as reliable detection approaches [61-63].
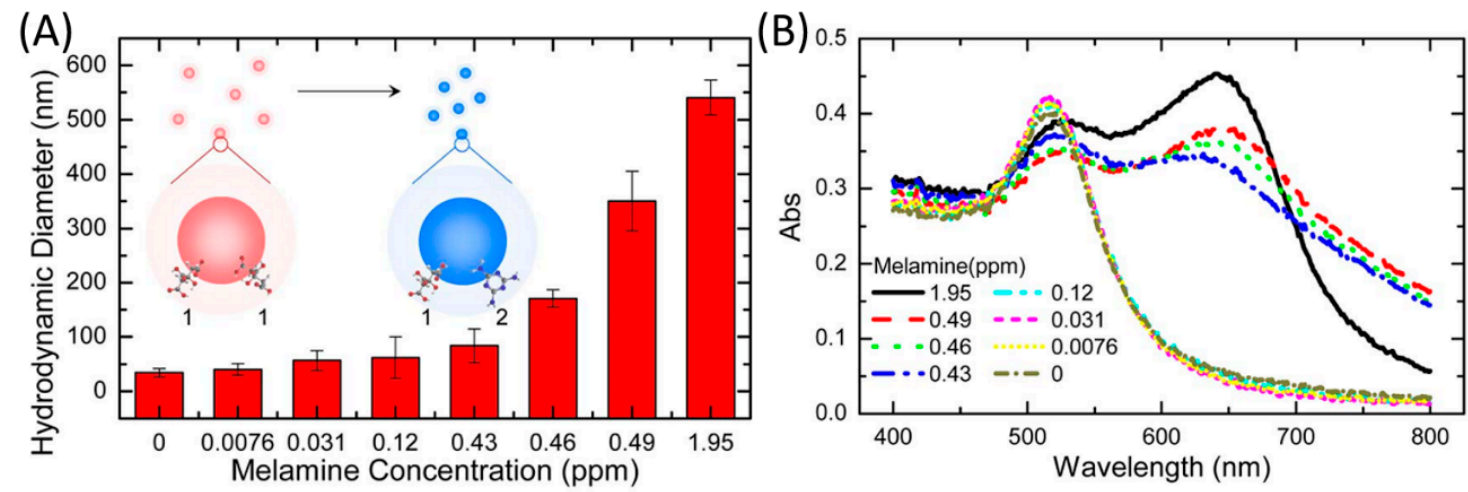

Figure 5. (A) Dynamic light scattering (DLS) demonstration of melamine concentration-dependent increases in particle size and (B) spectrophotometric demonstration of color shift. Reprinted with permission from Applied Physics Letters, 2010, 96, 133702. Copyright (2010) American Institute of Physics.

Insights into the mechanism by understanding the intrinsic interaction between melamine and the AuNPs surface would promote the development of unmodified AuNPs-based melamine detection strategy [59]. Primary amine groups and nitrogen atoms on the exocyclic ring skeleton of melamine could have a stronger interaction with AuNPs surface. Recent investigations have suggested that a surfactant of citrate ions on the AuNPs surface could be replaced by ligand exchange with multiple nitrogen sites of melamine [89]. Although no direct evidence has been reported to show how melamine is adsorbed on the AuNPs surface, related interaction studies give important hints to understand this key thermodynamic property. It has been reported that primary amine groups can be strongly bound to electron deficient surface sites of metal nanoparticles [106-108]. Two modes of bonding of amine molecules with AuNPs were identified: (a) weak electrostatic complex involving the protonated amine molecules with chloroaurate ions and (b) covalent bond of [AuCl( $\left.\left.\mathrm{NH}_{2} \mathrm{R}\right)\right]$ complexes [108]. The $\mathrm{AuCl}_{2}{ }^{-}$is one of several precursors during the sodium citrate induced reduction reaction of $\mathrm{AuCl}_{4}{ }^{-}$. The AuNPs surface would have many binding sites for molecules containing amine groups on either $\mathrm{AuCl}_{4}{ }^{-}$to $\mathrm{AuCl}_{2}{ }^{-}$. The sites provide coordination binding between melamine and the AuNPs surface. Furthermore, the nitrogen atoms on the exocyclic ring skeleton of adenine have a similar chemical structure, as melamine and nitrogen atoms have been demonstrated to coordinate with AuNPs surface. Hence, we suppose that three nitrogen atoms on the melamine exocyclic ring structure could bind to AuNPs surface, and three exocyclic primary amine groups would promote the formation of AuNP aggregation [59]. Several physical interaction factors influence melamine surface adsorption (e.g., surface charge density, Deby length, and thickness of electrical double layer). Thus, a more in depth understanding of the surface adsorption of melamine to AuNPs offers novel strategies to further develop the unmodified AuNPs-based colorimetric biosensor detection technique.

\subsection{DNA Detection}

A sequence specific approach for detecting DNA without the use of the lab complicated analytical equipment would be revolutionary for the diagnosis of genetic disorders and infectious pathogenic diseases. The use of unmodified or surface engineered AuNPs/AgNPs have been widely reported for visual DNA detection. AuNP and AgNP platforms provide nucleic acid detection system advantages 
with similar performances as other traditional diagnostic methods (fluorescence probe, RT-PCR, ELISA, and microarray assay). AuNPs/AgNPs/PtNPs-based colorimetric approaches with a high sensitivity and selectivity detection performance have been reported in literature in recent times (Table 2).

Table 2. Recent reported AuNPs-based colorimetric biosensors for DNA detection.

\begin{tabular}{cccccc}
\hline Nanomaterials & Detection Probe & $\begin{array}{c}\text { Instruments } \\
\text { Employed }\end{array}$ & Interaction & $\begin{array}{c}\text { Detection } \\
\text { Limit }\end{array}$ & Ref \\
\hline AuNPs & ssDNA/salt & PCR & Electrostatic & N/A & {$[109]$} \\
AuNPs & ssDNA/dsDNA & Naked eyes & Hybridization & $100 \mathrm{fM}$ & {$[110]$} \\
AuNPs & $\mathrm{K}^{+}$aptamer & Naked eyes & Uybridization & N/A & {$[74]$} \\
AuNPs & Hairpin & UV-vis & PCR Amplification & $5 \mathrm{pM}$ & {$[111]$} \\
AuNPs & ssDNA & UV-vis & Hybridization & N/A & {$[112]$} \\
AuNPs & ssDNA & UV-vis & Hybridization & $2.94 \mathrm{fM}$ & {$[113]$} \\
AuNPs & Unmodified & UV-vis & Hybridization & N/A & {$[114]$} \\
PtNPs & Graphene oxide & UV-vis & Peroxidase mimetic & $0.4 \mathrm{nM}$ & {$[115]$} \\
\hline
\end{tabular}

Elghanian et al. reported an approach to detect DNA while using DNA engineered AuNPs [51]. In the approach, single stranded thiolate mercaptoalkyl-oligonucleotides were conjugated onto AuNPs surface via thiol-gold interactions. The DNA engineered AuNPs have be used as colorimetric detection probes for nucleic acid detection. The conjugated single stranded DNA on the AuNPs surface could hybridize to 30 bases target DNA sequence via "Watson and Crick" A-T, G-C base pairing. Induced by the target DNA, the DNA engineered AuNPs could cross-link together by the complementary probes decorated on the AuNPs surface under the hybridization condition and form the AuNPs network. The colloidal AuNPs solution would have a distinguishable color shift (i.g., red to purple) as the AuNPs interparticle distance decrease. By transferring aggregation products to a reverse phase silica plate, the colorimetric changing degree could be used as a signal to achieve visual sensing. As a result, this revolutionary detection strategy provides a DNA LOD as low as 10 femtomoles. To further develop this strategy, the AuNPs surface was capped with 3'- and 5'-(alkanethiol) oligonucleotides, to complex a 24-based DNA target molecule [116]. This strategy could distinguish the target sequence with a probe tail, or a sequence with a single base pair deletion (a base pair insertion). Otherwise, Li et al. demonstrated utilizing unmodified AuNPs to detect single and double stranded DNA (Figure 6). The work reported on electrostatic interaction between single or double strand DNA and AuNPs. The results pointed out that the single strand DNA could adsorb onto the surface of citrate capped AuNPs with a rate that depends on the DNA sequence. After attaching to the unmodified AuNPs, the phosphate backbone of single strand DNA would promote colloid stabilization against the salt induced surface potential change. Based on this observation, label free AuNPs have been demonstrated for specific sequence detection without any surface functionalization chemistry. This strategy has been practiced on a clinical sample of genomic DNA for single nucleotide polymorphisms (SNPs) associated with a fatal arrhythmia known as long QT syndrome. The detecting result is visually determined and it does not need any analytical equipment.

Li et al. reported a critical coagulation concentration (CCC)-based salt titration method and used on unmodified AuNPs for visual detection and quantification of DNA concentration [65]. Single and double stranded DNA have a different surface binding strength with AuNPs. The colloid stability is directly dependent on the sequence length and temperature. Based on this intrinsic interaction between AuNPs and single or double strand DNA, Li et al. explored the possibility of utilizing CCC-based salt titration for single and double stranded DNA concentration quantitative detection. Visual quantification of DNA with the critical coagulation concentration-based salt titration and the effects of salt type, titration concentration, and volume interval have been studied and compared by titration step, volume, final CCC, and degree of color change. Unlike spectrometer-based DNA 
detection approaches, the CCC-based salt titration provides a visual quantification approach without sophisticated analytical equipment. CCC-based salt titration could be used as a highly suitable detection tool in situations of low setting resources without sacrificing sensitivity and accuracy.

(A)

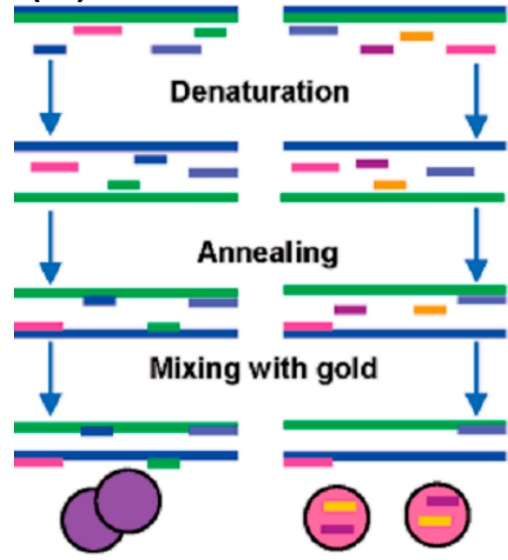

(B)

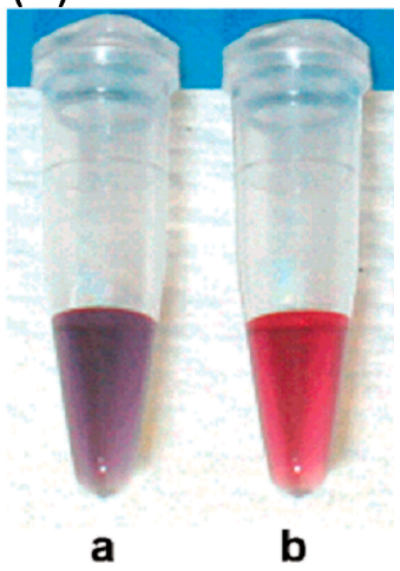

Figure 6. (A) Schematic of the detection protocol. The mixture of PCR product and probes is denatured and annealed below the melting temperature of the complementary probes followed by addition of gold colloid. The long blue and green lines represent the PCR-amplified DNA fragments, and the pink and light blue medium bars represent the excess PCR primers. The short blue and green bars are complementary probes that bind, resulting in Au-np aggregation (purple color). The short purple and orange bars are non-complementary probes that do not bind and adsorb to the Au-np, preventing Au-np aggregation and leaving the solution pink. (B) Color photographs of the resulting solutions with complementary probes (a) and non-complementary probes (b). Reprinted with permission from Journal of the American Chemical Society, 2004, 126, 10958-10961. Copyright (2004) American Chemical Society.

\section{3. $\mathrm{Hg}^{2+}$ Detection}

AuNPs and AgNPs have been widely used for the visual detection of toxic metals ions (i.g., $\left.\mathrm{Hg}^{2+}\right)$ [117]. $\mathrm{Hg}^{2+}$ have a strong interaction with sulfur and nitrogen atoms, and forms $\mathrm{S}-\mathrm{Hg}^{2+}-\mathrm{S}$ and $\mathrm{N}-\mathrm{Hg}^{2+}-\mathrm{N}$ compounds. Therefore, it provides a pathway for colorimetric biosensor detecting $\mathrm{Hg}^{2+}$ by the interaction between $\mathrm{Hg}^{2+}$ and NMNPs surface specific ligands with sulfur and nitrogen atoms. A number of ligands (i.g., dithioerythritol, cysteine, peptides, proteins, and DNA) with specific sulfur and nitrogen atoms have been decorated onto AuNPs and AgNPs for detecting $\mathrm{Hg}^{2+}$. The ligands interact with $\mathrm{Hg}^{2+}$ by a metal-ligand interaction and they cause the AuNPs and AgNPs a degree of aggregation with a rapid color change [118-120]. AuNPs/AgNPs/PtNPs-based colorimetric approaches with a high accuracy and selectivity detection performance have been reported in literature in recent times (Table 3).

In 2007, Lee et al. reported DNA engineered AuNPs for $\mathrm{Hg}^{2+}$ detection (Figure 7). A highly sensitive and selective DNA engineered AuNPs based on the thymidine $/ \mathrm{Hg}^{2+} /$ thymidine coordination chemistry was reported. This novel biosensor could be capable of selectively detecting $\mathrm{Hg}^{2+}$ in a nanomolar concentration range. $\mathrm{Hg}$-thymidine dimers have been extensively investigated due their high toxicity and denature of double stranded DNA [118]. The thermodynamic results indicated that $(\mathrm{A})_{10} \mathrm{~T}(\mathrm{~A})_{10}-(\mathrm{T})_{21}$ exhibit a much higher transition profile in the presence of $\mathrm{Hg}^{2+}$ than in its absence. When comparing with A- $\mathrm{T}$ pair interaction, $\mathrm{Hg}$ mediates $\mathrm{T}-\mathrm{Hg}$ - $\mathrm{T}$ dimers have been recognized as a much higher bonding energy. It is reported that there is no notable transition profile in the presence of other metal ions (i.g., $\mathrm{Ag}^{+}, \mathrm{Cu}^{2+}, \mathrm{Ni}^{2+}, \mathrm{Pd}^{2+}, \mathrm{Co}^{2+}, \mathrm{Mn}^{2+}, \mathrm{Zn}^{2+}, \mathrm{Pb}^{2+}, \mathrm{Cd}^{2+}, \mathrm{Mg}^{2+}, \mathrm{Ca}^{2+}, \mathrm{Fe}^{2+}$, $\mathrm{Fe}^{3+}$, and $\mathrm{Ru}^{2+}$ ). Therefore, this thermal transition evidence provide DNA engineered AuNPs with an excellent mean for selective and sensitive detection of $\mathrm{Hg}^{2+}$ ions. For instance, two complementary DNA sequence have been designed and modified onto AuNPs surface for detecting purpose. They 
are $5^{\prime} \mathrm{HS}-\mathrm{C}_{10}-\mathrm{A}_{10}-\mathrm{T}-\mathrm{A}_{10} 3^{\prime}$ and $5^{\prime} \mathrm{HS}-\mathrm{C}_{10}-\mathrm{T}_{10}-\mathrm{T}-\mathrm{T}_{10} 3^{\prime}$ with only one mismatch of $\mathrm{T}$ in the sequence. The mismatch pair could form a stable bond in the presence of $\mathrm{Hg}^{2+}$ by thymidine/ $\mathrm{Hg}^{2+} /$ thymidine complex. When comparing with the matched pair, two engineered AuNPs with mismatch probes exhibit a rapid color shift in the presence of $\mathrm{Hg}^{2+}$ [119]. Hence, this approach could be used as an idea tool to selectively detect $\mathrm{Hg}^{2+}$ in an aqueous environment. Otherwise, unmodified AuNPs with mercury specific oligonucleotides have been developed for $\mathrm{Hg}^{2+}$ colorimetric detection [121]. The approach is based on the interaction between single stranded DNA with AuNPs surface in the presence of $\mathrm{NaClO}_{4}$. The single stranded DNA has be sequence designed with a strong interaction with AuNPs surface by its nucleosides groups. Preventing by electrostatic repulsion force, the single stranded DNA on AuNPs surface could utilize its phosphate backbone to prevent AuNPs from the surface potential induced aggregation. When comparing with single stranded DNA, the double stranded DNA could not influence the AuNPs colloid stability. Double stranded DNA does not have free nucleoside groups, as single stranded DNA attach AuNPs surface and perform as surface electrostatic stabilizer. $\mathrm{Hg}^{2+}$ could induce single strand DNA folding into hairpin structure by the thymidine $/ \mathrm{Hg}^{2+}$ interaction. By removing the surface attached single stranded DNA, the method could be used as an idea tool to selectively detect $\mathrm{Hg}^{2+}$ as the DNA engineered AuNPs. Unmodified AgNPs exhibit a similar trend as DNA engineered AuNPs and achieved the $\mathrm{Hg}^{2+}$ LOD of $17 \mathrm{nM} \mathrm{[122].}$ Although AgNPs is unmodified, the specific single stranded DNA with reasonable $\mathrm{T}$ design showed a selective targeting behavior and it excludes the disturbance of other metal ions $\mathrm{Ag}^{+}, \mathrm{Cu}^{2+}, \mathrm{Ni}^{2+}, \mathrm{Pd}^{2+}$, $\mathrm{Co}^{2+}, \mathrm{Mn}^{2+}, \mathrm{Zn}^{2+}, \mathrm{Pb}^{2+}, \mathrm{Cd}^{2+}, \mathrm{Mg}^{2+}, \mathrm{Ca}^{2+}, \mathrm{Fe}^{2+}, \mathrm{Fe}^{3+}$, and $\mathrm{Ru}^{2+}$.

Table 3. Recent reported AuNPs/AgNPs/PtNPs-based colorimetric biosensors for $\mathrm{Hg}^{2+}$ detection.

\begin{tabular}{|c|c|c|c|c|c|}
\hline Nanomaterials & Detection Probe & $\begin{array}{l}\text { Instruments } \\
\text { Employed }\end{array}$ & Interaction & $\begin{array}{l}\text { Detection } \\
\text { Limit }\end{array}$ & Ref \\
\hline AuNPs & DNA & UV-vis & $\begin{array}{l}\text { Nitrogen } \\
\text { Interaction }\end{array}$ & $10 \mathrm{nM}$ & [119] \\
\hline AgNPs & Oligonucleotides & UV-vis & $\begin{array}{l}\text { Nitrogen } \\
\text { Interaction }\end{array}$ & $17 \mathrm{nM}$ & [121] \\
\hline AuNPs & $\begin{array}{c}\text { Citrate/Tween } 20 \\
\text { Hexadecyl }\end{array}$ & UV-vis & Redox reaction & $100 \mathrm{nM}$ & [123] \\
\hline AuNPs & $\begin{array}{c}\text { trimethyl } \\
\text { ammonium } \\
\text { bromide }(\mathrm{CTAB})\end{array}$ & UV-vis & Anti-aggregation & $11.9 \mathrm{nM}$ & [124] \\
\hline AuNPs & Thymine & UV-vis & $\begin{array}{l}\text { Nitrogen } \\
\text { Interaction }\end{array}$ & $10 \mathrm{nM}$ & [125] \\
\hline AuNPs & Thymine & UV-vis & $\begin{array}{l}\text { Nitrogen } \\
\text { Interaction }\end{array}$ & $3.6 \mathrm{pM}$ & [126] \\
\hline AuNPs & $\begin{array}{l}\text { Hydrogen } \\
\text { peroxide }\end{array}$ & UV-vis & Redox reaction & $8.9 \mathrm{pM}$ & [127] \\
\hline AgNPs & Alginate & Naked eyes & Redox reaction & $5.3 \mathrm{nM}$ & [128] \\
\hline AgNPs & Thiamine & $\begin{array}{c}\text { Naked eyes } \\
\text { UV-vis }\end{array}$ & $\begin{array}{l}\text { Nitrogen/Sulfur } \\
\text { Interaction }\end{array}$ & $5 \mathrm{nM}$ & [129] \\
\hline AgNPs & Sodium cholate & $\begin{array}{c}\text { Naked eyes } \\
\text { UV-vis }\end{array}$ & Redox reaction & $12 \mathrm{nM}$ & [130] \\
\hline AgNPs & Melamine & $\begin{array}{c}\text { Naked eyes } \\
\text { UV-vis }\end{array}$ & $\begin{array}{l}\text { Nitrogen } \\
\text { Interaction }\end{array}$ & $1.8 \mathrm{pM}$ & [131] \\
\hline PtNPs & Citrate & UV-vis & $\begin{array}{l}\text { Inhibition } \\
\text { peroxidase }\end{array}$ & $8.5 \mathrm{pM}$ & [132] \\
\hline PtNPs & $\begin{array}{c}\text { Organic } \\
\text { frameworks }\end{array}$ & UV-vis & $\begin{array}{l}\text { Inhibition } \\
\text { peroxidase }\end{array}$ & $0.35 \mathrm{nM}$ & [133] \\
\hline
\end{tabular}




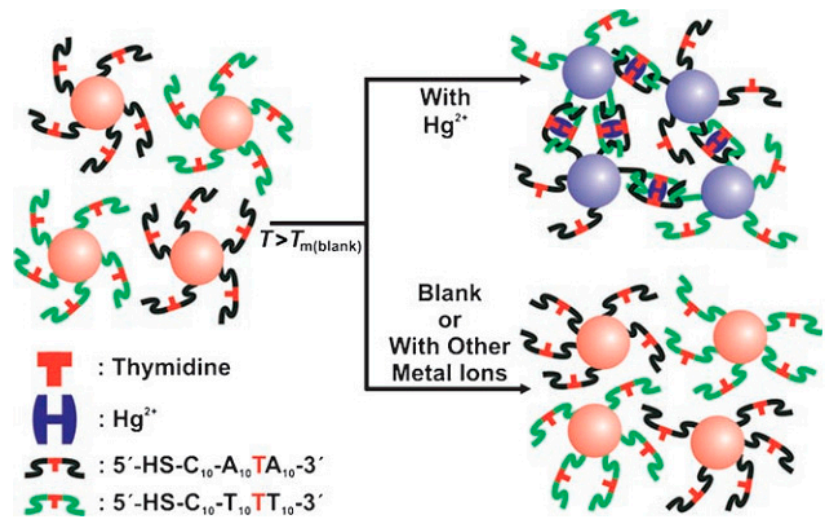

Figure 7. Colorimetric detection of mercuric ion $\left(\mathrm{Hg}^{2+}\right)$ using DNA-AuNPs. Reprinted with permission from Angewandte Chemie Internaltional Edition, 2007, 46, 4093-4096. Copyright (2007) John Wiley \& Sons, Inc.

\subsection{Protein Detection}

AuNPs and AgNPs based colorimetric biosensors for protein detection is a major research interdisciplinary area between chemistry, biology, and nanotechnology. The development of protein detection methodologies are extensively required, as the target protein is considered as an important index involved in medical diagnostics, pathogen detection, and proteomics. AuNPs/AgNPs based colorimetric approaches with high accuracy and selectivity performance have been reported in literature in recent times (Table 4).

Table 4. Recent reported AuNPs/AgNPs-based colorimetric biosensors for protein detection.

\begin{tabular}{|c|c|c|c|c|c|c|}
\hline Nanomaterials & $\begin{array}{l}\text { Detection } \\
\text { Probe }\end{array}$ & Analyses & $\begin{array}{l}\text { Instruments } \\
\text { Employed }\end{array}$ & Interaction & $\begin{array}{l}\text { Detection } \\
\text { Limit }\end{array}$ & Ref \\
\hline AuNPs & $\begin{array}{c}\text { ssDNA/ } \\
\text { polyelectrolyte }\end{array}$ & Proteins & UV-vis & DNA folding & $\begin{array}{l}\text { Pico } \\
\text { molar }\end{array}$ & [134] \\
\hline AuNPs/AgNPs & Unmodified & $\begin{array}{l}\text { Bacteria } \\
\text { proteins }\end{array}$ & $\begin{array}{c}\text { Naked eyes } \\
\text { UV-vis }\end{array}$ & Non-specific & $0.5 \mu \mathrm{M}$ & [135] \\
\hline AuNPs & Unmodified & Thrombin & $\begin{array}{c}\text { Naked eyes } \\
\text { UV-vis }\end{array}$ & DNA folding & $0.83 \mathrm{nM}$ & [136] \\
\hline AgNPs & Aptamer & Thrombin & $\begin{array}{c}\text { Naked eyes } \\
\text { UV-vis }\end{array}$ & Microfluid chip & $20 \mathrm{pM}$ & [137] \\
\hline AuNPs & Polymer/aptmer & Lysozyme & UV-vis & Crosslinking & $4.4 \mathrm{nM}$ & [138] \\
\hline AuNPs & Aptamer & PDGFs & UV-vis & Specific binding & $3.2 \mathrm{nM}$ & [139] \\
\hline AuNPs & Peptide & MMP-7 & UV-vis & $\begin{array}{l}\text { Peptide } \\
\text { interaction }\end{array}$ & $5 \mathrm{nM}$ & [140] \\
\hline
\end{tabular}

The most extensively protein detection methods are mass spectrometry with electrospray ionization (ESI) and matrix-assisted laser desorption ionization (MALDI), and enzyme-linked immunosorbent assay (ELISA), which have been widely used in research and clinical labs for precise protein quantitation. However, the high accuracy analytical equipment suffer from some drawbacks (i.g., complex protocols, high cost, time consuming, large test sample requirements). To further satisfy the convenient methodologies for protein detection requirement, NMNPs based biosensor have been develop and seen progress in the colorimetric and visual detection of a various proteins (i.g., thrombin, lysozyme, platelet derived growth factors (PDGFs), and matrix metalloproteinase-7 (MMP-7)) [141,142]. Based on the "aggregation strategy", AuNPs have been functionalized with carbohydrate probes as "glyconanometarials" and are used as excellent colorimetric biosensor platforms for protein detection. Carbohydrate and protein have an intermolecular and intramolecular interaction between protein and carbohydrate moieties. Otsuka et al. reported PEGylated AuNPs with distal end decorated with 
lactose (Lac) to selectively detect Recinus Communis Agglutinin $\left(\mathrm{RCA}_{120}\right)$ [143]. $\mathrm{RCA}_{120}$ is a bivalent lectin that could interact with the galactose residue. $\mathrm{RCA}_{120}$ induces the Lac-AuNPs aggregation with a pinkish-red to purple color shift and this aggregation state is reversible by adding galactose to achieve Lac-AuNPs recycling function with a LOD of $1 \mathrm{ppm}$. Takae et al. further develop this idea by processing various functionalities of lactose ligand on the PEG (0 to 65\%) to study the ligand density influencing the binding affinity with lectin [144]. The PEGylated AuNPs with $40 \%$ and $65 \%$ lactose show a time dependent kinetic aggregation behavior and it indicates that the optimization of ligand surface density could prevent nonspecific interactions by the PEG layer to promote the AuNPs-based biosensor sensitivity. Wang et al. undertake the fundamental study and reported using dissociation constant $\left(\mathrm{K}_{\mathrm{d}}\right)$ to evaluate the binding affinity between glyconanoparticles and proteins [145]. Lectin has been used as the protein mode and AuNPs have been decorated with mono-, oligo-, and polysaccharides with different linker type, spacer length, and ligand density. The results indicate that the longer spacer would provide a highest binding strength with ligand density increase, as AuNPs would enhance this interaction by decreasing the size. Aptamer-based protein detection strategy is another interesting strategy that has been applied on AuNPs/AgNPs-based colorimetric biosensors for protein detection [146,147]. Aptamers (single stranded DNA oligonucleotides) can interact with targeting molecules by their specific secondary structure and they provide a new bio-recognition platform. Based on the specific interaction with protein, aptamers have been decorated onto AuNPs surface or used as label free to achieve the protein detection goal. For instance, Huang et al. developed aptamer modified AuNPs as a highly specific sensing system for three PDGFs detection [139]. Aptamer used to conjugate onto AuNPs surface in a three-way helix junction with a conserved single stranded loop at the branch point. The aptamer has a high binding affinity with PDGFs (AA) with a $K_{d}$ value of $10 \mathrm{nM}$ and $0.1 \mathrm{nM}$ with PDGFs (BB and AB). After decorating onto AuNPs surface by thiol-gold reaction, the sensitivity of Apt-AuNPs have a salt dependent behavior, with an optimum condition of $200 \mathrm{mM} \mathrm{NaCl}$ with LODs at nanomolar level. Aptamer-based unmodified AuNPs have been reported as a colorimetric method for protein detection. Wei et al. reported a simple and sensitive method for thrombin detection by aptamer label free AuNPs [136]. This method avoid the conjugating technique causing the problems (i.g., complex protocols, weakened affinity). It is reported that thrombin and its corresponding 29-mer binding aptamer have been used as model to study the AuNPs based colorimetric detection. Thrombin could competitively bind with 29-mer aptamer and induced AuNPs surface attached 29-mer aptamers forming G-quadruplex/duplex. AuNPs would lose the stability after the interaction occurred and the AuNPs aggregation would be promoted by a high salt concentration environment. The result indicate that the thrombin induced colorimetric degree is linear correlated to the thrombin concentration with LOD of $0.83 \mathrm{nM}$. Besides two classic strategies, Xia et al. reported "universal" unmodified AuNPs based biosensor to detect small molecules, proteins, and ions by the interaction between free single/double stranded DNA with the cationic polyelectrolyte in the presence of thrombin with LOD $10 \mathrm{nM} \mathrm{[134].}$ Chen et al. have reported peptide functionalized AuNPs by the thiol group of cysteine residue for matrix metalloproteinase-7 (MMP-7) with a LOD of $5 \mathrm{nM}$ [140]. Li et al. reported utilizing the AuNPs and AgNPs for the naked eye detection of proteins by the colorimetric sensor array [135]. Thomas et al. have reported the interaction of AuNPs with protein cationic regions for the potential development of AuNPs based analytical assay [148]. All of the interesting works demonstrate the AuNPs and AgNPs have the practical potential to be developed as a rapid, sensitive, cost-effective and reliable biosensors for the future protein detection.

\section{Conclusions and Outlook}

NMNPs based biosensor would be an ideal detection tool for the future visual quantification. The SPR effect and high extinction coefficient of NMNPs make them ideal visual probes for colorimetric based analytical applications, including visual detection and spectrometry. The NMNPs intrinsic merits would promote researchers continuing develop NMNPs as a sensitive and selective biosensor. However, NMNPs based colorimetric biosensors are developed under laboratory settings. Transferring 
them into "on-shelf" products need to overcome the main difficulties: (1) reproducible of NMNPs large scale synthesis; (2) consistent NMNPs shape and size by batch; (3) stability and denaturation of NMNPs surface conjugated biomolecule ligands; and, (4) interferences causes sensitivity/selectivity problems by the cellular components, tissues, and etc. [149]. To avoid the shortcomings, the development of NMNPs surface conjugation techniques and the understanding of interaction between NMNPs surface and analyses provide two suggestions for advancing the development of NMNPs based colorimetric biosensors. As the development of NMNPs surface conjugation technique, bimolecular ligand candidates could be decorated onto NMNPs surface with a high biostability and yield, low time cost, and less complexity protocols. DNA engineered NMNPs would directly benefit from the technique by conjugating biological molecules (i.g., aptamers, peptides, and oligonucleotides) utilizing the specific interaction with analyses to achieve high detection performance. With the further understanding of the interaction between NMNPs surface and analyses, the non-crosslinking strategy provides NMNPs based colorimetric biosensors another pathway by easy controlling physical factors to improve the performance of sensing assay. Inspired by this idea, the CCC salt titration approach has been developed and it is comparable to other sensing assays by optimizing condition to achieve a more sensitive detection goal. In collusion, NMNPs colorimetric biosensors are user friendly, adaptable, inexpensive, and do not require complex analytical instruments. They would offer a wide range of potential applications, including environmental testing, food safety, and biomedical industries in the future.

Author Contributions: The manuscript was written through contributions of all authors. All authors have given approval to the final version of the manuscript.

Funding: This research received no external funding.

Acknowledgments: I would like to express my special thanks of gratitude to my colleague Benjamin T. Ledford for helping us do the literature editing and proofreading.

Conflicts of Interest: The authors declare no conflict of interest.

\section{References}

1. Doria, G.; Conde, J.; Veigas, B.; Giestas, L.; Almeida, C.; Assuncao, M.; Rosa, J.; Baptista, P.V. Noble Metal Nanoparticles for Biosensing Applications. Sensors 2012, 12, 1657-1687. [CrossRef] [PubMed]

2. Malekzad, H.; Zangabad, P.S.; Mirshekari, H.; Karimi, M.; Hamblin, M.R. Noble metal nanoparticles in biosensors: Recent studies and applications. Nanotechnol. Rev. 2017, 6, 301-329. [CrossRef] [PubMed]

3. Azharuddin, M.; Zhu, G.H.; Das, D.; Ozgur, E.; Uzun, L.; Turner, A.P.F.; Patra, H.K. A repertoire of biomedical applications of noble metal nanoparticles. Chem. Commun. 2019, 55, 6964-6996. [CrossRef] [PubMed]

4. Sau, T.K.; Rogach, A.L.; Jackel, F.; Klar, T.A.; Feldmann, J. Properties and Applications of Colloidal Nonspherical Noble Metal Nanoparticles. Adv. Mater. 2010, 22, 1805-1825. [CrossRef]

5. Arvizo, R.R.; Bhattacharyya, S.; Kudgus, R.A.; Giri, K.; Bhattacharya, R.; Mukherjee, P. Intrinsic therapeutic applications of noble metal nanoparticles: Past, present and future. Chem. Soc. Rev. 2012, 41, 2943-2970. [CrossRef]

6. Turkevich, J.; Stevenson, P.C.; Hillier, J. A Study of the Nucleation and Growth Processes in the Synthesis of Colloidal Gold. Discuss. Faraday Soc. 1951, 11, 55-75. [CrossRef]

7. Frens, G. Controlled Nucleation for Regulation of Particle-Size in Monodisperse Gold Suspensions. Nat.-Phys. Sci. 1973, 241, 20-22. [CrossRef]

8. Kimling, J.; Maier, M.; Okenve, B.; Kotaidis, V.; Ballot, H.; Plech, A. Turkevich method for gold nanoparticle synthesis revisited. J. Phys. Chem. B 2006, 110, 15700-15707. [CrossRef]

9. Bastus, N.G.; Merkoci, F.; Piella, J.; Puntes, V. Synthesis of Highly Monodisperse Citrate-Stabilized Silver Nanoparticles of up to 200 nm: Kinetic Control and Catalytic Properties. Chem. Mat. 2014, 26, 2836-2846. [CrossRef]

10. Wuithschick, M.; Birnbaum, A.; Witte, S.; Sztucki, M.; Vainio, U.; Pinna, N.; Rademann, K.; Emmerling, F.; Kraehnert, R.; Polte, J. Turkevich in New Robes: Key Questions Answered for the Most Common Gold Nanoparticle Synthesis. ACS Nano 2015, 9, 7052-7071. [CrossRef] 
11. Ji, X.H.; Song, X.N.; Li, J.; Bai, Y.B.; Yang, W.S.; Peng, X.G. Size control of gold nanocrystals in citrate reduction: The third role of citrate. J. Am. Chem. Soc. 2007, 129, 13939-13948. [CrossRef] [PubMed]

12. Wu, X.M.; Redmond, P.L.; Liu, H.T.; Chen, Y.H.; Steigerwald, M.; Brus, L. Photovoltage mechanism for room light conversion of citrate stabilized silver nanocrystal seeds to large nanoprisms. J. Am. Chem. Soc. 2008, 130, 9500-9506. [CrossRef] [PubMed]

13. Dong, X.Y.; Ji, X.H.; Wu, H.L.; Zhao, L.L.; Li, J.; Yang, W.S. Shape Control of Silver Nanoparticles by Stepwise Citrate Reduction. J. Phys. Chem. C 2009, 113, 6573-6576. [CrossRef]

14. Rycenga, M.; Cobley, C.M.; Zeng, J.; Li, W.Y.; Moran, C.H.; Zhang, Q.; Qin, D.; Xia, Y.N. Controlling the Synthesis and Assembly of Silver Nanostructures for Plasmonic Applications. Chem. Rev. 2011, 111, 3669-3712. [CrossRef]

15. Slot, J.W.; Geuze, H.J. A New Method of Preparing Gold Probes For Multiple-Labeling Cyto-Chemistry. Eur. J. Cell Biol. 1985, 38, 87-93.

16. Brust, M.; Walker, M.; Bethell, D.; Schiffrin, D.J.; Whyman, R. Synthesis of Thiol-Derivatized Gold Nanoparticles in a 2-Phase Liquid-Liquid System. J. Chem. Soc.-Chem. Commun. 1994, 801-802. [CrossRef]

17. Goulet, P.J.G.; Lennox, R.B. New Insights into Brust-Schiffrin Metal Nanoparticle Synthesis. J. Am. Chem. Soc. 2010, 132, 9582-9584. [CrossRef]

18. Li, Y.; Zaluzhna, O.; Xu, B.L.; Gao, Y.A.; Modest, J.M.; Tong, Y.J. Mechanistic Insights into the Brust-Shiffrin Two-Phase Synthesis of Organo-chalcogenate-Protected Metal Nanoparticles. J. Am. Chem. Soc. 2011, 133, 2092-2095. [CrossRef]

19. Perala, S.R.K.; Kumar, S. On the Mechanism of Metal Nanoparticle Synthesis in the Brust-Schiffrin Method. Langmuir 2013, 29, 9863-9873. [CrossRef]

20. Zhang, X.F.; Liu, Z.G.; Shen, W.; Gurunathan, S. Silver Nanoparticles: Synthesis, Characterization, Properties, Applications, and Therapeutic Approaches. Int. J. Mol. Sci. 2016, 17, 34. [CrossRef]

21. De Souza, C.D.; Nogueira, B.R.; Rostelato, M. Review of the methodologies used in the synthesis gold nanoparticles by chemical reduction. J. Alloy. Compd. 2019, 798, 714-740. [CrossRef]

22. Jana, N.R.; Gearheart, L.; Murphy, C.J. Seeding growth for size control of 5-40 nm diameter gold nanoparticles. Langmuir 2001, 17, 6782-6786. [CrossRef]

23. Niu, W.X.; Zhang, L.; Xu, G.B. Seed-mediated growth method for high-quality noble metal nanocrystals. Sci. China-Chem. 2012, 55, 2311-2317. [CrossRef]

24. Wei, G.T.; Yang, Z.S.; Lee, C.Y.; Yang, H.Y.; Wang, C.R.C. Aqueous-organic phase transfer of gold nanoparticles and gold nanorods using an ionic liquid. J. Am. Chem. Soc. 2004, 126, 5036-5037. [CrossRef]

25. Cui, P.L.; He, H.Y.; Chen, D.; Liu, H.; Zhang, S.J.; Yang, J. Phase Transfer of Noble Metal Nanoparticles from Ionic Liquids to an Organic/Aqueous Medium. Ind. Eng. Chem. Res. 2014, 53, 15909-15916. [CrossRef]

26. Husanu, E.; Chiappe, C.; Bernardini, A.; Cappello, V.; Gemmi, M. Synthesis of colloidal Ag nanoparticles with citrate based ionic liquids as reducing and capping agents. Colloid Surf. A-Physicochem. Eng. Asp. 2018, 538, 506-512. [CrossRef]

27. McFarland, A.D.; Haynes, C.L.; Mirkin, C.A.; Van Duyne, R.P.; Godwin, H.A. Color my nanoworld. J. Chem. Educ. 2004, 81, 544A. [CrossRef]

28. Ravindran, A.; Chandran, P.; Khan, S.S. Biofunctionalized silver nanoparticles: Advances and prospects. Colloid Surf. B-Biointerfaces 2013, 105, 342-352. [CrossRef]

29. Barbillon, G. Plasmonics and its Applications. Materials 2019, 12, 4. [CrossRef]

30. Jain, P.K.; Huang, X.H.; El-Sayed, I.H.; El-Sayed, M.A. Noble Metals on the Nanoscale: Optical and Photothermal Properties and Some Applications in Imaging, Sensing, Biology, and Medicine. Accounts Chem. Res. 2008, 41, 1578-1586. [CrossRef]

31. Olenin, A.Y. Chemically Modified Silver and Gold Nanoparticles in Spectrometric Analysis. J. Anal. Chem. 2019, 74, 355-375. [CrossRef]

32. Sperling, R.A.; Parak, W.J. Surface modification, functionalization and bioconjugation of colloidal inorganic nanoparticles. Philos. Trans. R. Soc. A-Math. Phys. Eng. Sci. 2010, 368, 1333-1383. [CrossRef] [PubMed]

33. Chen, Y.P.; Xianyu, Y.L.; Jiang, X.Y. Surface Modification of Gold Nanoparticles with Small Molecules for Biochemical Analysis. Accounts Chem. Res. 2017, 50, 310-319. [CrossRef] [PubMed]

34. Hurst, S.J.; Lytton-Jean, A.K.R.; Mirkin, C.A. Maximizing DNA loading on a range of gold nanoparticle sizes. Anal. Chem. 2006, 78, 8313-8318. [CrossRef] [PubMed] 
35. Hughes, Z.E.; Walsh, T.R. Non-covalent adsorption of amino acid analogues on noble-metal nanoparticles: Influence of edges and vertices. Phys. Chem. Chem. Phys. 2016, 18, 17525-17533. [CrossRef]

36. Yu, Y.; Zou, J.; Yu, L.; Jo, W.; Li, Y.K.; Law, W.C.; Cheng, C. Functional Polylactide-g-Paclitaxel-Poly(ethylene glycol) by Azide-Alkyne Click Chemistry. Macromolecules 2011, 44, 4793-4800. [CrossRef]

37. Poonthiyil, V.; Lindhorst, T.K.; Golovko, V.B.; Fairbanks, A.J. Recent applications of click chemistry for the functionalization of gold nanoparticles and their conversion to glyco-gold nanoparticles. Beilstein J. Org. Chem. 2018, 14, 11-24. [CrossRef]

38. Daniel, M.C.; Astruc, D. Gold nanoparticles: Assembly, supramolecular chemistry, quantum-size-related properties, and applications toward biology, catalysis, and nanotechnology. Chem. Rev. 2004, 104, 293-346. [CrossRef]

39. Giljohann, D.A.; Seferos, D.S.; Daniel, W.L.; Massich, M.D.; Patel, P.C.; Mirkin, C.A. Gold Nanoparticles for Biology and Medicine. Angew. Chem.-Int. Edit. 2010, 49, 3280-3294. [CrossRef]

40. Rai, M.K.; Deshmukh, S.D.; Ingle, A.P.; Gade, A.K. Silver nanoparticles: The powerful nanoweapon against multidrug-resistant bacteria. J. Appl. Microbiol. 2012, 112, 841-852. [CrossRef]

41. Wei, L.Y.; Lu, J.R.; Xu, H.Z.; Patel, A.; Chen, Z.S.; Chen, G.F. Silver nanoparticles: Synthesis, properties, and therapeutic applications. Drug Discov. Today 2015, 20, 595-601. [CrossRef] [PubMed]

42. Dreaden, E.C.; Alkilany, A.M.; Huang, X.H.; Murphy, C.J.; El-Sayed, M.A. The golden age: Gold nanoparticles for biomedicine. Chem. Soc. Rev. 2012, 41, 2740-2779. [CrossRef] [PubMed]

43. Zhang, Z.Y.; Wang, H.; Chen, Z.P.; Wang, X.Y.; Choo, J.; Chen, L.X. Plasmonic colorimetric sensors based on etching and growth of noble metal nanoparticles: Strategies and applications. Biosens. Bioelectron. 2018, 114, 52-65. [CrossRef] [PubMed]

44. Vilela, D.; Gonzalez, M.C.; Escarpa, A. Sensing colorimetric approaches based on gold and silver nanoparticles aggregation: Chemical creativity behind the assay. A review. Anal. Chim. Acta 2012, 751, 24-43. [CrossRef] [PubMed]

45. Xue, X.J.; Wang, F.; Liu, X.G. One-step, room temperature, colorimetric detection of mercury (Hg2+) using DNA/nanoparticle conjugates. J. Am. Chem. Soc. 2008, 130, 3244-3245. [CrossRef]

46. Mei, B.C.; Susumu, K.; Medintz, I.L.; Delehanty, J.B.; Mountziaris, T.J.; Mattoussi, H. Modular poly(ethylene glycol) ligands for biocompatible semiconductor and gold nanocrystals with extended $\mathrm{pH}$ and ionic stability. J. Mater. Chem. 2008, 18, 4949-4958. [CrossRef]

47. Tsai, D.H.; DelRio, F.W.; MacCuspie, R.I.; Cho, T.J.; Zachariah, M.R.; Hackley, V.A. Competitive Adsorption of Thiolated Polyethylene Glycol and Mercaptopropionic Acid on Gold Nanoparticles Measured by Physical Characterization Methods. Langmuir 2010, 26, 10325-10333. [CrossRef]

48. Hostetler, M.J.; Wingate, J.E.; Zhong, C.J.; Harris, J.E.; Vachet, R.W.; Clark, M.R.; Londono, J.D.; Green, S.J.; Stokes, J.J.; Wignall, G.D.; et al. Alkanethiolate gold cluster molecules with core diameters from 1.5 to $5.2 \mathrm{~nm}$ : Core and monolayer properties as a function of core size. Langmuir 1998, 14, 17-30. [CrossRef]

49. Woehrle, G.H.; Brown, L.O.; Hutchison, J.E. Thiol-functionalized, 1.5-nm gold nanoparticles through ligand exchange reactions: Scope and mechanism of ligand exchange. J. Am. Chem. Soc. 2005, 127, 2172-2183. [CrossRef]

50. Zhang, X.; Servos, M.R.; Liu, J.W. Fast pH-assisted functionalization of silver nanoparticles with monothiolated DNA. Chem. Commun. 2012, 48, 10114-10116. [CrossRef]

51. Elghanian, R.; Storhoff, J.J.; Mucic, R.C.; Letsinger, R.L.; Mirkin, C.A. Selective colorimetric detection of polynucleotides based on the distance-dependent optical properties of gold nanoparticles. Science 1997, 277, 1078-1081. [CrossRef] [PubMed]

52. Zou, J.; Yu, Y.; Yu, L.; Li, Y.K.; Chen, C.K.; Cheng, C. Well-Defined Drug-Conjugated Biodegradable Nanoparticles by Azide-Alkyne Click Crosslinking in Miniemulsion. J. Polym. Sci. Pol. Chem. 2012, 50, 142-148. [CrossRef]

53. Storhoff, J.J.; Lazarides, A.A.; Mucic, R.C.; Mirkin, C.A.; Letsinger, R.L.; Schatz, G.C. What controls the optical properties of DNA-linked gold nanoparticle assemblies? J. Am. Chem. Soc. 2000, 122, 4640-4650. [CrossRef]

54. Thanh, N.T.K.; Rosenzweig, Z. Development of an aggregation-based immunoassay for anti-protein A using gold nanoparticles. Anal. Chem. 2002, 74, 1624-1628. [CrossRef] [PubMed]

55. Liu, J.; Lu, Y. Preparation of aptamer-linked gold nanoparticle purple aggregates for colorimetric sensing of analytes. Nat. Protoc. 2006, 1, 246-252. [CrossRef] 
56. Li, N.; Ho, C.M. Aptamer-based optical probes with separated molecular recognition and signal transduction modules. J. Am. Chem. Soc. 2008, 130, 2380-2381. [CrossRef]

57. Liu, J.W.; Lu, Y. Fast colorimetric sensing of adenosine and cocaine based on a general sensor design involving aptamers and nanoparticles. Angew. Chem.-Int. Edit. 2006, 45, 90-94. [CrossRef]

58. Yu, L.; Gao, Y.G.; Yue, X.L.; Liu, S.Q.; Dai, Z.F. Novel Hollow Microcapsules Based on Iron-Heparin Complex Multilayers. Langmuir 2008, 24, 13723-13729. [CrossRef]

59. Wei, F.; Lam, R.; Cheng, S.; Lu, S.; Ho, D.A.; Li, N. Rapid detection of melamine in whole milk mediated by unmodified gold nanoparticles. Appl. Phys. Lett. 2010, 96, 3. [CrossRef]

60. Wei, H.; Li, B.L.; Li, J.; Dong, S.J.; Wang, E.K. DNAzyme-based colorimetric sensing of lead $(\mathrm{Pb}(2+))$ using unmodified gold nanoparticle probes. Nanotechnology 2008, 19, 5. [CrossRef]

61. Chi, H.; Liu, B.H.; Guan, G.J.; Zhang, Z.P.; Han, M.Y. A simple, reliable and sensitive colorimetric visualization of melamine in milk by unmodified gold nanoparticles. Analyst 2010, 135, 1070-1075. [CrossRef]

62. Chen, W.; Deng, H.H.; Hong, L.; Wu, Z.Q.; Wang, S.; Liu, A.L.; Lin, X.H.; Xia, X.H. Bare gold nanoparticles as facile and sensitive colorimetric probe for melamine detection. Analyst 2012, 137, 5382-5386. [CrossRef]

63. Guan, H.A.; Yu, J.; Chi, D.F. Label-free colorimetric sensing of melamine based on chitosan-stabilized gold nanoparticles probes. Food Control 2013, 32, 35-41. [CrossRef]

64. Liu, J.W. Adsorption of DNA onto gold nanoparticles and graphene oxide: Surface science and applications. Phys. Chem. Chem. Phys. 2012, 14, 10485-10496. [CrossRef]

65. Li, N.; Yu, L.; Zou, J.Q. Critical Coagulation Concentration-Based Salt Titration for Visual Quantification in Gold Nanoparticle-Based Colorimetric Biosensors. Jala 2014, 19, 82-90. [CrossRef]

66. Li, N.; Yu, L.; Zou, J.Q. A Colorimetric Method for Assessing the Adsorption Strength of Oligonucleotides on Noble Metal Nanoparticles. In Proceedings of the 9th IEEE International Conference on Nano/Molecular Medicine and Engineering, Honolulu, HI, USA, 15-18 November 2015; pp. 43-46.

67. Yu, L.; Li, N. Binding Strength of Nucleobases and Nucleosides on Silver Nanoparticles Probed by a Colorimetric Method. Langmuir 2016, 32, 5510-5518. [CrossRef]

68. Dubertret, B.; Calame, M.; Libchaber, A.J. Single-mismatch detection using gold-quenched fluorescent oligonucleotides. Nat. Biotechnol. 2001, 19, 365-370. [CrossRef]

69. Kimura-Suda, H.; Petrovykh, D.Y.; Tarlov, M.J.; Whitman, L.J. Base-dependent competitive adsorption of single-stranded DNA on gold. J. Am. Chem. Soc. 2003, 125, 9014-9015. [CrossRef]

70. Takashima, A.; Oishi, M. Kinetic study of DNA hybridization on DNA-modified gold nanoparticles with engineered nano-interfaces. RSC Adv. 2015, 5, 76014-76018. [CrossRef]

71. Chen, C.L.; Wang, W.J.; Ge, J.; Zhao, X.S. Kinetics and thermodynamics of DNA hybridization on gold nanoparticles. Nucleic Acids Res. 2009, 37, 3756-3765. [CrossRef]

72. Sandstrom, P.; Boncheva, M.; Akerman, B. Nonspecific and thiol-specific binding of DNA to gold nanoparticles. Langmuir 2003, 19, 7537-7543. [CrossRef]

73. Li, H.X.; Rothberg, L.J. DNA sequence detection using selective fluorescence quenching of tagged oligonucleotide probes by gold nanoparticles. Anal. Chem. 2004, 76, 5414-5417. [CrossRef]

74. Wang, L.H.; Liu, X.F.; Hu, X.F.; Song, S.P.; Fan, C.H. Unmodified gold nanoparticles as a colorimetric probe for potassium DNA aptamers. Chem. Commun. 2006, 36, 3780-3782. [CrossRef]

75. Hsu, J.P.; Liu, B.T. Critical coagulation concentration of a colloidal suspension at high particle concentrations. J. Phys. Chem. B 1998, 102, 334-337. [CrossRef]

76. Garcia-Garcia, S.; Wold, S.; Jonsson, M. Kinetic determination of critical coagulation concentrations for sodium- and calcium-montmorillonite colloids in $\mathrm{NaCl}$ and $\mathrm{CaCl} 2$ aqueous solutions. J. Colloid Interface Sci. 2007, 315, 512-519. [CrossRef]

77. Liu, L.C.; Moreno, L.; Neretnieks, I. A Novel Approach to Determine the Critical Coagulation Concentration of a Colloidal Dispersion with Plate-like Particles. Langmuir 2009, 25, 688-697. [CrossRef]

78. Nowicki, W.; Nowicka, G. Verification of the Schulze-Hardy Rule - a Colloid Chemistry Experiment. J. Chem. Educ. 1994, 71, 624-626. [CrossRef]

79. Metcalfe, I.M.; Healy, T.W. Charge-Regulation Modeling of the Schulze-Hardy Rule and Related Coagulation Effects. Faraday Discuss. 1990, 90, 335-344. [CrossRef]

80. Yu, L.; Tran, T.V.; Zou, J.Q.; Li, N. Probing the Mechanism of Melamine-Induced Gold Nanoparticle Aggregation. In Proceedings of the 6th IEEE International Conference on Nano/Molecular Medicine and Engineering, Bangkok, Thailand, 4-7 November 2012; pp. 21-26. 
81. Liu, D.B.; Wang, Z.; Jiang, X.Y. Gold nanoparticles for the colorimetric and fluorescent detection of ions and small organic molecules. Nanoscale 2011, 3, 1421-1433. [CrossRef]

82. Saha, K.; Agasti, S.S.; Kim, C.; Li, X.N.; Rotello, V.M. Gold Nanoparticles in Chemical and Biological Sensing. Chem. Rev. 2012, 112, 2739-2779. [CrossRef]

83. Lee, K.S.; El-Sayed, M.A. Gold and silver nanoparticles in sensing and imaging: Sensitivity of plasmon response to size, shape, and metal composition. J. Phys. Chem. B 2006, 110, 19220-19225. [CrossRef]

84. Shellaiah, M.; Sun, K.W. Review on Nanomaterial-Based Melamine Detection. Chemosensors $2019,7,47$. [CrossRef]

85. Huang, G.M.; Zheng, O.Y.; Cooks, R.G. High-throughput trace melamine analysis in complex mixtures. Chem. Commun. 2009, 5, 556-558. [CrossRef]

86. Sun, F.X.; Ma, W.; Xu, L.G.; Zhu, Y.Y.; Liu, L.Q.; Peng, C.F.; Wang, L.B.; Kuang, H.; Xu, C.L. Analytical methods and recent developments in the detection of melamine. Trac-Trends Anal. Chem. 2010, 29, 1239-1249. [CrossRef]

87. Li, L.; Li, B.X.; Cheng, D.; Mao, L.H. Visual detection of melamine in raw milk using gold nanoparticles as colorimetric probe. Food Chem. 2010, 122, 895-900. [CrossRef]

88. Guo, L.Q.; Zhong, J.H.; Wu, J.M.; Fu, F.F.; Chen, G.N.; Zheng, X.Y.; Lin, S. Visual detection of melamine in milk products by label-free gold nanoparticles. Talanta 2010, 82, 1654-1658. [CrossRef]

89. Kuang, H.; Chen, W.; Yan, W.J.; Xu, L.G.; Zhu, Y.Y.; Liu, L.Q.; Chu, H.Q.; Peng, C.F.; Wang, L.B.; Kotov, N.A.; et al. Crown ether assembly of gold nanoparticles: Melamine sensor. Biosens. Bioelectron. 2011, 26, $2032-2037$. [CrossRef]

90. Su, H.C.; Fan, H.; Ai, S.Y.; Wu, N.; Fan, H.M.; Bian, P.C.; Liu, J.C. Selective determination of melamine in milk samples using 3-mercapto-1-propanesulfonate-modified gold nanoparticles as colorimetric probe. Talanta 2011, 85, 1338-1343. [CrossRef]

91. Xiao, C.; Zhang, X.F.; Liu, J.F.; Yang, A.K.; Zhao, H.; Li, X.J.; He, Y.J.; Yuan, Z.B. Sensitive colorimetric detection of melamine with 1,4-dithiothreitol modified gold nanoparticles. Anal. Methods 2015, 7, 924-929. [CrossRef]

92. Yin, M.L.; Zhao, L.F.; Wei, Q.; Li, H. Rapid colorimetric detection of melamine by H2O2-Au nanoparticles. RSC Adv. 2015, 5, 32897-32901. [CrossRef]

93. Chang, K.K.; Wang, S.; Zhang, H.; Guo, Q.Q.; Hu, X.R.; Lin, Z.L.; Sun, H.F.; Jiang, M.; Hu, J.D. Colorimetric detection of melamine in milk by using gold nanoparticles-based LSPR via optical fibers. PLoS ONE 2017, 12, e0177131. [CrossRef] [PubMed]

94. Zheng, H.R.; Li, Y.; Xu, J.Y.; Bie, J.X.; Liu, X.; Guo, J.J.; Luo, Y.L.; Shen, F.; Sun, C.Y.; Yu, Y.L. Highly Sensitive Aptamer-Based Colorimetric Detection of Melamine in Raw Milk with Cysteamine-Stabilized Gold Nanoparticles. J. Nanosci. Nanotechnol. 2017, 17, 853-861. [CrossRef] [PubMed]

95. Chen, X.Y.; Ha, W.; Shi, Y.P. Sensitive colorimetric detection of melamine in processed raw milk using asymmetrically PEGylated gold nanoparticles. Talanta 2019, 194, 475-484. [CrossRef] [PubMed]

96. Hu, X.R.; Chang, K.K.; Wang, S.; Sun, X.Q.; Hu, J.D.; Jiang, M. Aptamer-functionalized AuNPs for the high-sensitivity colorimetric detection of melamine in milk samples. PLoS ONE 2018, 13, e0201626. [CrossRef]

97. Ma, Y.R.; Niu, H.Y.; Zhang, X.L.; Cai, Y.Q. One-step synthesis of silver/dopamine nanoparticles and visual detection of melamine in raw milk. Analyst 2011, 136, 4192-4196. [CrossRef]

98. Xavier, S.S.J.; Karthikeyan, C.; Kumar, G.G.; Kim, A.R.; Yoo, D.J. Colorimetric detection of melamine using beta-cyclodextrin-functionalized silver nanoparticles. Anal. Methods 2014, 6, 8165-8172. [CrossRef]

99. Varun, S.; Daniel, S.; Gorthi, S.S. Rapid sensing of melamine in milk by interference green synthesis of silver nanoparticles. Mater. Sci. Eng. C-Mater. Biol. Appl. 2017, 74, 253-258. [CrossRef]

100. Farrokhnia, M.; Karimi, S.; Askarian, S. Strong Hydrogen Bonding of Gallic Acid during Synthesis of an Efficient AgNPs Colorimetric Sensor for Melamine Detection via Dis-synthesis Strategy. ACS Sustain. Chem. Eng. 2019, 7, 6672-6684. [CrossRef]

101. Rajar, K.; Sirajuddin; Balouch, A.; Bhanger, M.I.; Shah, M.T.; Shaikh, T.; Siddiqui, S. Succinic acid functionalized silver nanoparticles (Suc-Ag NPs) for colorimetric sensing of melamine. Appl. Surf. Sci. 2018, 435, 1080-1086. [CrossRef]

102. Alam, M.F.; Laskar, A.A.; Ahmed, S.; Shaida, M.A.; Younus, H. Colorimetric method for the detection of melamine using in-situ formed silver nanoparticles via tannic acid. Spectroc. Acta Pt. A-Molec. Biomolec. Spectr. 2017, 183, 17-22. [CrossRef] 
103. Kumar, N.; Kumar, H.; Mann, B.; Seth, R. Colorimetric determination of melamine in milk using unmodified silver nanoparticles. Spectroc. Acta Pt. A-Molec. Biomolec. Spectr. 2016, 156, 89-97. [CrossRef] [PubMed]

104. Ai, K.L.; Liu, Y.L.; Lu, L.H. Hydrogen-Bonding Recognition-Induced Color Change of Gold Nanoparticles for Visual Detection of Melamine in Raw Milk and Infant Formula. J. Am. Chem. Soc. 2009, 131, 9496-9497. [CrossRef] [PubMed]

105. Peng, J.J.; Guo, H.; Li, Y.F.; Wang, Y.H.; Chen, W.Y.; Wang, A.J. Single Molecular Functionalized Gold Nanoparticles for Hydrogen-Bonding Recognition and Colorimetric Detection of Dopamine with High Sensitivity and Selectivity. ACS Appl. Mater. Interfaces 2013, 5, 1226-1231. [CrossRef]

106. Weitz, D.A.; Lin, M.Y.; Sandroff, C.J. Colloidal Aggregation Revisited-New Insights Based on Fractal Structure and Suraace-Enhanced Raman-Scattering. Surf. Sci. 1985, 158, 147-164. [CrossRef]

107. Leff, D.V.; Brandt, L.; Heath, J.R. Synthesis and characterization of hydrophobic, organically-soluble gold nanocrystals functionalized with primary amines. Langmuir 1996, 12, 4723-4730. [CrossRef]

108. Kumar, A.; Mandal, S.; Selvakannan, P.R.; Pasricha, R.; Mandale, A.B.; Sastry, M. Investigation into the interaction between surface-bound alkylamines and gold nanoparticles. Langmuir 2003, 19, 6277-6282. [CrossRef]

109. Li, H.X.; Rothberg, L.J. Label-free colorimetric detection of specific sequences in genomic DNA amplified by the polymerase chain reaction. J. Am. Chem. Soc. 2004, 126, 10958-10961. [CrossRef]

110. Li, H.X.; Rothberg, L. Colorimetric detection of DNA sequences based on electrostatic interactions with unmodified gold nanoparticles. Proc. Natl. Acad. Sci. USA 2004, 101, 14036-14039. [CrossRef]

111. Zou, L.; Li, R.M.; Zhang, M.J.; Luo, Y.W.; Zhou, N.; Wang, J.; Ling, L.S. A colorimetric sensing platform based upon recognizing hybridization chain reaction products with oligonucleotide modified gold nanoparticles through triplex formation. Nanoscale 2017, 9, 1986-1992. [CrossRef]

112. Wang, G.Q.; Akiyama, Y.; Shiraishi, S.; Kanayama, N.; Takarada, T.; Maeda, M. Cross-Linking versus Non-Cross-Linking Aggregation of Gold Nanoparticles Induced by DNA Hybridization: A Comparison of the Rapidity of Solution Color Change. Bioconjugate Chem. 2017, 28, 270-277. [CrossRef]

113. Baetsen-Young, A.M.; Vasher, M.; Matta, L.L.; Colgan, P.; Alocilja, E.C.; Day, B. Direct colorimetric detection of unamplified pathogen DNA by dextrin capped gold nanoparticles. Biosens. Bioelectron. 2018, 101, 29-36. [CrossRef] [PubMed]

114. Gopinath, S.C.B.; Lakshmipriya, T.; Awazu, K. Colorimetric detection of controlled assembly and disassembly of aptamers on unmodified gold nanoparticles. Biosens. Bioelectron. 2014, 51, 115-123. [CrossRef] [PubMed]

115. Chau, L.Y.; He, Q.J.; Qin, A.L.; Yip, S.P.; Lee, T.M.H. Platinum nanoparticles on reduced graphene oxide as peroxidase mimetics for the colorimetric detection of specific DNA sequence. J. Mat. Chem. B 2016, 4, 4076-4083. [CrossRef]

116. Storhoff, J.J.; Elghanian, R.; Mucic, R.C.; Mirkin, C.A.; Letsinger, R.L. One-pot colorimetric differentiation of polynucleotides with single base imperfections using gold nanoparticle probes. J. Am. Chem. Soc. 1998, 120, 1959-1964. [CrossRef]

117. Zarlaida, F.; Adlim, M. Gold and silver nanoparticles and indicator dyes as active agents in colorimetric spot and strip tests for mercury(II) ions: A review. Microchim. Acta 2017, 184, 45-58. [CrossRef]

118. Miyake, Y.; Togashi, H.; Tashiro, M.; Yamaguchi, H.; Oda, S.; Kudo, M.; Tanaka, Y.; Kondo, Y.; Sawa, R.; Fujimoto, T.; et al. Mercury(II)-mediated formation of thymine-Hg-II-thymine base pairs in DNA duplexes. J. Am. Chem. Soc. 2006, 128, 2172-2173. [CrossRef]

119. Lee, J.S.; Han, M.S.; Mirkin, C.A. Colorimetric detection of mercuric ion (Hg2+) in aqueous media using DNA-functionalized gold nanoparticles. Angew. Chem.-Int. Edit. 2007, 46, 4093-4096. [CrossRef]

120. Slocik, J.M.; Zabinski, J.S.; Phillips, D.M.; Naik, R.R. Colorimetric response of peptide-functionalized gold nanoparticles to metal ions. Small 2008, 4, 548-551. [CrossRef]

121. Wang, Y.; Yang, F.; Yang, X.R. Colorimetric Detection of Mercury(II) Ion Using Unmodified Silver Nanoparticles and Mercury-Specific Oligonucleotides. ACS Appl. Mater. Interfaces 2010, 2, 339-342. [CrossRef]

122. Li, D.; Wieckowska, A.; Willner, I. Optical analysis of $\mathrm{Hg}(2+)$ ions by oligonucleotide-gold-nanoparticle hybrids and DNA-based machines. Angew. Chem.-Int. Edit. 2008, 47, 3927-3931. [CrossRef]

123. Lin, C.Y.; Yu, C.J.; Lin, Y.H.; Tseng, W.L. Colorimetric Sensing of Silver(I) and Mercury(II) Ions Based on an Assembly of Tween 20-Stabilized Gold Nanoparticles. Anal. Chem. 2010, 82, 6830-6837. [CrossRef] 
124. Sun, X.X.; Liu, R.X.; Liu, Q.W.; Fei, Q.; Feng, G.D.; Shan, H.Y.; Huan, Y.F. Colorimetric sensing of mercury (II) ion based on anti-aggregation of gold nanoparticles in the presence of hexadecyl trimethyl ammonium bromide. Sens. Actuator B-Chem. 2018, 260, 998-1003. [CrossRef]

125. Aulsebrook, M.L.; Watkins, E.; Grace, M.R.; Graham, B.; Tuck, K.L. Modified Gold Nanoparticles for the Temperature-Dependent Colorimetric Detection of Mercury and Methylmercury. ChemistrySelect 2018, 3, 2088-2091. [CrossRef]

126. Zeng, G.M.; Zhang, C.; Huang, D.L.; Lai, C.; Tang, L.; Zhou, Y.Y.; Xu, P.A.; Wang, H.; Qin, L.; Cheng, M. Practical and regenerable electrochemical aptasensor based on nanoporous gold and thymine-Hg2+-thymine base pairs for $\mathrm{Hg} 2+$ detection. Biosens. Bioelectron. 2017, 90, 542-548. [CrossRef] [PubMed]

127. Zhou, Y.; Ma, Z.F. Colorimetric detection of $\mathrm{Hg} 2+$ by Au nanoparticles formed by $\mathrm{H} 2 \mathrm{O} 2$ reduction of $\mathrm{HAuCl} 4$ using Au nanoclusters as the catalyst. Sens. Actuator B-Chem. 2017, 241, 1063-1068. [CrossRef]

128. Faghiri, F.; Ghorbani, F. Colorimetric and naked eye detection of trace $\mathrm{Hg} 2+$ ions in the environmental water samples based on plasmonic response of sodium alginate impregnated by silver nanoparticles. J. Hazard. Mater. 2019, 374, 329-340. [CrossRef] [PubMed]

129. Khan, U.; Niaz, A.; Shah, A.; Zaman, M.I.; Zia, M.A.; Iftikhar, F.J.; Nisar, J.; Ahmed, M.N.; Akhter, M.S.; Shah, A.H. Thiamine-functionalized silver nanoparticles for the highly selective and sensitive colorimetric detection of Hg2+ ions. New J. Chem. 2018, 42, 528-534. [CrossRef]

130. Marimuthu, V.; Chandirasekar, S.; Rajendiran, N. Green Synthesis of Sodium Cholate Stabilized Silver Nanoparticles: An Effective Colorimetric Sensor for Hg2+ and Pb2+ Ions. ChemistrySelect 2018, 3, 3918-3924. [CrossRef]

131. Kailasa, S.K.; Chandel, M.; Mehta, V.N.; Park, T.J. Influence of ligand chemistry on silver nanoparticles for colorimetric detection of $\mathrm{Cr} 3+$ and Hg2+ ions. Spectroc. Acta Pt. A-Molec. Biomolec. Spectr. 2018, 195, 120-127. [CrossRef]

132. Wu, G.W.; He, S.B.; Peng, H.P.; Deng, H.H.; Liu, A.L.; Lin, X.H.; Xia, X.H.; Chen, W. Citrate-Capped Platinum Nanoparticle as a Smart Probe for Ultrasensitive Mercury Sensing. Anal. Chem. 2014, 86, 10955-10960. [CrossRef]

133. Li, H.P.; Liu, H.F.; Zhang, J.D.; Cheng, Y.X.; Zhang, C.L.; Fei, X.Y.; Xian, Y.Z. Platinum Nanoparticle Encapsulated Metal-Organic Frameworks for Colorimetric Measurement and Facile Removal of Mercury(II). ACS Appl. Mater. Interfaces 2017, 9, 40716-40725. [CrossRef] [PubMed]

134. Xia, F.; Zuo, X.L.; Yang, R.Q.; Xiao, Y.; Kang, D.; Vallee-Belisle, A.; Gong, X.; Yuen, J.D.; Hsu, B.B.Y.; Heeger, A.J.; et al. Colorimetric detection of DNA, small molecules, proteins, and ions using unmodified gold nanoparticles and conjugated polyelectrolytes. Proc. Natl. Acad. Sci. USA 2010, 107, 10837-10841. [CrossRef] [PubMed]

135. Li, D.Y.; Dong, Y.H.; Li, B.Y.; Wu, Y.Y.; Wang, K.; Zhang, S.C. Colorimetric sensor array with unmodified noble metal nanoparticles for naked-eye detection of proteins and bacteria. Analyst 2015, 140, 7672-7677. [CrossRef] [PubMed]

136. Wei, H.; Li, B.L.; Li, J.; Wang, E.K.; Dong, S.J. Simple and sensitive aptamer-based colorimetric sensing of protein using unmodified gold nanoparticle probes. Chem. Commun. 2007, 36, 3735-3737. [CrossRef]

137. Zhao, Y.J.; Liu, X.H.; Li, J.; Qiang, W.B.; Sun, L.; Li, H.; Xu, D.K. Microfluidic chip-based silver nanoparticles aptasensor for colorimetric detection of thrombin. Talanta 2016, 150, 81-87. [CrossRef]

138. Yao, X.; Ma, X.D.; Ding, C.; Jia, L. Colorimetric determination of lysozyme based on the aggregation of gold nanoparticles controlled by a cationic polymer and an aptamer. Microchim. Acta 2016, 183, 2353-2359. [CrossRef]

139. Huang, C.C.; Huang, Y.F.; Cao, Z.H.; Tan, W.H.; Chang, H.T. Aptamer-modified gold nanoparticles for colorimetric determination of platelet-derived growth factors and their receptors. Anal. Chem. 2005, 77, 5735-5741. [CrossRef]

140. Chen, P.; Selegard, R.; Aili, D.; Liedberg, B. Peptide functionalized gold nanoparticles for colorimetric detection of matrilysin (MMP-7) activity. Nanoscale 2013, 5, 8973-8976. [CrossRef]

141. He, S.; Liu, D.B.; Wang, Z.; Cai, K.Y.; Jiang, X.Y. Utilization of unmodified gold nanoparticles in colorimetric detection. Sci. China-Phys. Mech. Astron. 2011, 54, 1757-1765. [CrossRef]

142. Sabela, M.; Balme, S.; Bechelany, M.; Janot, J.M.; Bisetty, K. A Review of Gold and Silver Nanoparticle-Based Colorimetric Sensing Assays. Adv. Eng. Mater. 2017, 19, 24. [CrossRef] 
143. Otsuka, H.; Akiyama, Y.; Nagasaki, Y.; Kataoka, K. Quantitative and reversible lectin-induced association of gold nanoparticles modified with alpha-lactosyl-omega-mercapto-poly(ethylene glycol). J. Am. Chem. Soc. 2001, 123, 8226-8230. [CrossRef] [PubMed]

144. Takae, S.; Akiyama, Y.; Otsuka, H.; Nakamura, T.; Nagasaki, Y.; Kataoka, K. Ligand density effect on biorecognition by PEGylated gold nanoparticles: Regulated interaction of RCA(120) lectin with lactose installed to the distal end of tethered PEG strands on gold surface. Biomacromolecules 2005, 6, 818-824. [CrossRef] [PubMed]

145. Wang, X.; Ramstrom, O.; Yan, M.D. Quantitative Analysis of Multivalent Ligand Presentation on Gold Glyconanoparticles and the Impact on Lectin Binding. Anal. Chem. 2010, 82, 9082-9089. [CrossRef] [PubMed]

146. Zhao, W.A.; Chiuman, W.; Lam, J.C.F.; McManus, S.A.; Chen, W.; Cui, Y.G.; Pelton, R.; Brook, M.A.; Li, Y.F. DNA aptamer folding on gold nanoparticles: From colloid chemistry to biosensors. J. Am. Chem. Soc. 2008, 130, 3610-3618. [CrossRef]

147. Strehlitz, B.; Nikolaus, N.; Stoltenburg, R. Protein detection with aptamer biosensors. Sensors 2008, 8, 4296-4307. [CrossRef]

148. Pires, T.A.; Narovec, C.M.; Whelan, R.J. Effects of Cationic Proteins on Gold Nanoparticle/Aptamer Assays. ACS Omega 2017, 2, 8222-8226. [CrossRef]

149. Aldewachi, H.; Chalati, T.; Woodroofe, M.N.; Bricklebank, N.; Sharrack, B.; Gardiner, P. Gold nanoparticlebased colorimetric biosensors. Nanoscale 2018, 10, 18-33. [CrossRef]

(C) 2019 by the authors. Licensee MDPI, Basel, Switzerland. This article is an open access article distributed under the terms and conditions of the Creative Commons Attribution (CC BY) license (http://creativecommons.org/licenses/by/4.0/). 